\title{
DEVLET BAŞKANININ HALK TARAFINDAN SEÇIMI YÖNTEMLERİ
}

\author{
Abdurrahman TEKIN*
}

\section{$\ddot{O} Z$}

Birleşmiş Milletler tarafindan tanınan ülkelerin 108'inde devlet başkanı doğrudan halk tarafindan seçilerek göreve gelmektedir. Parlamenter sistemlerde dahi devlet başkanı seçiminin halka bırakılması eğiliminin başladığını söylemek mümkündür. Hatta bu durum, hükümet sistemleri bağlamında kalıplaşmış tasnif ve yargıların da yıkılmasını hızlandırmıştır.

Devlet başkanlı̆̆ı makamı Bosna istisna tutulursa tek bir kişiye tahsis edilen bir makam olduğu için uygulanan seçim sistemlerinin mantığı da oldukça yalındır: Mutlak veya basit çoğunluk ile en çok oyu alan aday ilk veya takip eden turda/turlarda seçilmektedir. "Illk başta baklldığında" devlet başkanlı̆̆ seçiminde, milletvekili seçim sistemlerinde olduğu gibi seçim çevrelerinin büyüklüğü, seçim çevrelerinin coğrafi sınırlarının belirlenmesi, ulusal veya seçim çevresi barajı, oyların hesaplanmasında kullanılan metotlar gibi karmaşık unsurlar bulunmamaktadır. Ancak "detaylara inildiğinde” devlet başkanının seçiminde uygulanan zikredilen yalın yönteme ilaveten, oldukça farklı ve karmaşık yol ve yöntemlerin var olabildiği görülmektedir.

Bu çalışmada tüm Dünya ülkelerindeki veriler incelenerek halk tarafindan devlet başkanlarının hangi yöntemler ile seçildiği incelenmiş ve bir tasnif yapılmıştır. Uygulanan seçim sistemlerinin olumlu ve olumsuz yanları seçim sonuçlar ile desteklenerek ortaya koyulmuştur.

Anahtar Kelimeler: Devlet Başkanı - Cumhurbaşkanının Seçimi, Seçim Sistemi, Basit Çoğunluk, Mutlak Çoğunluk, Tek Turlu, İki Turlu.

\section{METHODS FOR ELECTION OF HEAD OF STATE BY PUBLIC}

\section{ABSTRACT}

Heads of states come to power after being directly elected by public in 108 states worldwide out of those recognised by the United Nations. It can be asserted that parliamentary systems are getting more inclined to allow for public to directly vote for their heads of states. This disposition has accelerated elimination and dismissal of

* Dr. Öğr. Üyesi, Yalova Üniversitesi Hukuk Fakültesi, Anayasa Hukuku ABD Öğretim Üyesi /Yalova, e-posta: tekinabdurrahman@hotmail.com,

ORCID: 0000-0003-3041-3941

DOI : 10.34246/ahbvuhfd.1018783

Yayın Kuruluna Ulaştığı Tarih : 09/05/2021

Yayınlanmasının Uygun Görüldüğü Tarih: 20/08/2021 
stereotyped classifications and presumptions in government systems.

As the post of head of state refers to a position exclusively assigned to a single person (with exception of Bosnia), logic of applicable electoral systems seems quite simple: the candidate with the highest number of votes by simple or absolute majority is elected in the first or ensuing round/s. At first glance at election of heads of states, it seems that such complicated factors as size of electoral district, determination of geographical borders of electoral districts, election thresholds either at national level or peculiar to electoral districts, methods of counting and calculating the votes, as observed in electoral systems for deputies, do not play any role. Nevertheless, when a closer look is given at details, it is figured out that the above-mentioned simple method applicable to election of heads of states might also be accompanied by quite diverse and complicated methods and procedures.

After having compiled and examined the relevant data about all the states in the world, this study has analysed and classified the range of methods employed in election of heads of states by public. Additionally, positive and negative aspects and repercussions of these applicable electoral systems are presented in light of election results.

Key Words: Election of Head of State - President, Election System, Simple Majority, Absolute Majority, Majority Run-off.

\section{Giriş}

Toplumların, tarihten günümüze farklı şekilde sınıflandırıldığ görülmektedir. Yaygın sıralama, ilkel toplumdan kent toplumuna, sonrasında feodal topluma ve nihayetinde ise ulusa geçiş şeklinde bir değişimin olduğu görülmektedir. İlkel toplumlarda dahi toplum olmanın doğal bir sonucu olarak herkesi bağlayan bir kurallar bütünü ve bunların uygulayıcısı konumunda bulunan iktidar ${ }^{1}$ ile karşılaşılmaktadır. ${ }^{2}$ Bir diğer ifade ile ilkel toplumların dahi, bir liderin varlığı göze çarpmaktadır. Şef veya savaş önderi gibi isimler

1 Devlet öncesi yapılarda da iktidar olgusu ile karşılaşıldığından dolayı, iktidar olgusunu tarihsel olarak devlet ile eşzamanlı başlatmamak gerekir. Bkz. Nihat Bulut, Siyasal İktidar Tipleri ve Bir Siyasal İktidar Tipi Olarak (Modern) Devlet, 2020, <http://cdn.istanbul.edu. tr/FileHandler2.ashx?f=siyasal-iktidar-tipleri-vebir-siyasal-tipi-olarak-modern-devlet.pdf $>$ Erişim Tarihi 18 Nisan 2020.

2 Bunun aksi de elbette ki görülebilir. Ancak kurallar bütünü ve iktidardan yoksun olan grupları toplum olarak nitelememek, bunları kalabalıklar veya gruplar şeklinde kabul etmek gerekecektir. Uygun, 16-18. 
ile anılan liderlerin varlığı insanoğlunun iyi yönetim için bir karar vericiye her daim ihtiyaç duyduğunun bir göstergesidir. ${ }^{3}$ İlkel toplumlarda da gözlemlenen liderler, toplum yapısındaki değişim ile birlikte her daim görülmüştür. Bunun günümüz karşılı̆̆ 1 ise devlet başkanıdır. Devlet başkanlığı makamı, anayasaların bulduğu bir kavram değil; tarihsel olarak kurulmuş bir şekilde anayasaların karşısına çıkmış bir kavram olarak kabul edilmektedir. ${ }^{4}$

Modern demokrasilerin doğmasından önceki dönemlerde "genel olarak" devlet başkanlarının mutlak bir güce sahip olduğu, iktidara gelişin irsi usullere bağlandığı, hiçbir hukuki ve siyasi sorumluluğunun olmadığ görülmektedir. Hatta devlet başkanının sahip olduğu egemenliğin kaynağının dine dayandırılarak, makama duyulacak saygı ve makamı işgal edenin meşruiyetinin arttırılmaya çalışıldığ 1 da bilinmektedir. ${ }^{5}$ Ancak siyasal iktidarın ${ }^{6}$ tamamının sahibi olan devlet başkanının bu gücünde anayasacılık ile ciddi kırılmalar meydana gelmiştir. Modern devlet ile ortaya çıkan anayasacılık olgusu, XVIII. yüzyılda liberal devlet anlayışı ile birlikte doğmuştur. Liberal devletin özünde, iktidarın üstün bir norm ile sınırlandırılması anlayışı yatmaktadır. ${ }^{7} \mathrm{Bu}$ sınırlandırma ise anayasalarca çerçevesi çizilecek şekilde kuvvetlerin birbirinden ayrılması ile mümkün olmaktadır. Bir diğer ifade ile devlet başkanlarının siyasi iktidar sahibi olma konumu, anayasacılık ve kuvvetler ayrılığı ile ciddi bir erozyona uğramıştır. Böylece mutlak gücün sahibi olan devlet başkanının, iktidarı paylaşmak zorunda kaldığ 1 bir döneme girilmiştir. Girilen bu dönem, devlet başkanının etkisiz ve sembolik yetkilerle donatılmasıyla veya önemli birtakım yetkileri haiz ancak halk tarafından o makama getirilen bir kişiliğe dönüşüm ile sonuçlanmıştır. Yaşanan bu dönüşümün sağlanmasında meclislerin etkinleşmesini de unutmamak gerekmektedir. Özellikle İngiltere'de etkin bir şekilde faaliyet gösteren ve neredeyse fasılasız bir şekilde günümüze kadar gelen meclisler, monarkın yetkilerini bulduğu her firsatta adeta kendine nakletmişler ve bu durum diğer

Oktay Uygun, Devlet Teorisi, On iki levha, 2017, s. 3-38. Aristo da benzer düşüncede olup, insanoğlunun hayatta kalması için bir arada hareket etmesi ve bu birlikteliği sürdürebilmek için bir lidere ihtiyaç duyması eşyanın tabiatındandır görüşündedir. Bkz. Michael G. Roskin/ Robert L. Cord/ James A. Medeiros/ Walter S. Jones, Political Science an Introduction, 12. bs., Pearson, 2012, s. 9.

4 Kemal Gözler, Devlet Başkanları, 2. Bask1, Ekin, 2016, s. 1.

5 Ömer Anayurt, Anayasa Hukuku Genel Kısım, 3. Bask1, Seçkin, 2020, s. 250-252.

6 Siyasal iktidar kavramı, siyaset bilimi terminolojisinde sadece yürütmeyi değil, yasama yürütme ve yargı iktidarının toplamı için kullanılmaktadır. Bkz. Uygun, s. 3.

7 Abdurrahman Eren, Anayasa Hukuku Dersleri, 2. Bask1, Seçkin, 2020, S. 107. 
devletlerin meclislerince de taklit edilmiştir. ${ }^{8}$

Devlet başkanlığı makamının devlet iktidarı üzerindeki egemen yapısının kırılmasında kuvvetler ayrılığının yeri de önem arz etmektedir. Karma yönetim anlayışının sona ermeye başlaması, irsi usullerle gelen idareciler ve soyluların karar verici makamlarda olmasından duyulan rahatsızlıklar, feodalitenin yıkımı ve Montesquieu ve Locke gibi düşünürlerin katkıları, iktidarın sadece halk tarafindan kullanılması fikrinin gelişmesine katkı sunmuş ve kuvvetlerin ayrılığının temelleri atılıışır.9

Kuvvetler ayrıllğı teorisi, günümüzde liberal demokrasilerin en önemli şartı olarak görülmektedir. Tek bir kişinin elinde olan siyasal iktidarın, son iki yüzyılda meclis ile paylaşılmaya başlanması sonucu ortaya çıkan pratik, bu ayrılığın gerekliliğinin pek çok devletlerce de benimsenmesini sağlamıştır. Anayasaların yapılması ile yürütmenin yetkileri hukuk ile sınırlandırılmış ve meclis odaklı bir çağın kapıları açılarak yürütmenin bir adım geriye gittiği gözlenmiştir. ${ }^{10}$ Böylece devlet başkanları, bir zamanlar siyasi iktidarın tek sahibi iken, zamanla bu iktidarın bölündüğü görülmüştür. Bölünen iktidarın en güçlü kolu olan devlet başkanları, zamanla bu üstünlüğü de meclislere kaptırmıştır. Devlet başkanının üstünlüğünden meclisin üstünlügü anlayışına geçilmesi ile gelişen süreç bir değişime daha uğramıştır. II. Dünya Savaş1 döneminde Rousseau'nun genel irade teorisinin yanlış uygulanarak meclis desteği ile tiranlıklar doğuran İtalya ve Almanya örneklerinden edinilen tecrübe ile hukukun, anayasanın üstünlügü süreci başlatılmıştır. ${ }^{11}$

Günümüzde, liberal demokrasi kavramı bağlamında, her ne kadar anayasanın üstünlüğü anlayışında bir geriye gidiş söz konusu olmasa da devlet organları arasında bir iktidar mücadelesinin varlı̆̆ 1 hala göze

8 Meclislerin bu dönemde güçlenme süreci hakkında daha fazla bilgi için Bkz: Abdurrahman Tekin, Liberal Anayasal Sistemlerde Parlamento İçi Muhalefetin Rolü, On İki Levha, 2019, s. 31-35.

9 Steven G. Calabresi/ Mark E. Berghausen/ Skylar Albertson, "The Rise and Fall of the Separation of Powers", 2012, 106(2), Northwestern University Law Review, s. 527-53; Tekin, s. 42.

10 Bu noktada yargı organını da unutmamak gerekir. Sınırlı iktidar kavramının içselleştirilmesi ile yargı sadece halk arasında değil devlet organları arasında da hakem görevi üstlenir olmuş ve diğer organlardan ayrıştırılmış ve onların hukukun çizdiği sınırlar dahilinde kalmasını sağlamıştır.

11 Anayurt, s. 673-676. 
çarpmaktadır. ${ }^{12}$ Etkisizleşmeye başlayan devlet başkanlığı makamı, eski konumunu hukukun çizdiği sınırlar dahilinde elde etme mücadelesi içerisine girmiştir. Nitekim yakın geçmişte yaşanan gelişmelerden, hürriyetçi demokrasilerde, yürütmenin, bilhassa devlet başkanlarının, görev ve devlet içindeki ağırlığında bir artış görülmektedir. ${ }^{13}$ Artan bu ağırlık genellikle hükümet sistemi değişikliği ile açıklanmaktadır. Kimi durumlarda da güçlü bir liderin devlet başkanlığı makamına oturması sonrası gelen fiili bir durumdan kaynaklanmaktadır. Devlet başkanlarının daha hızlı karar alabilmeleri ve ilgili reformları daha kolay hayata geçirebilmesi sebebiyle bu yönelimin olduğunu zikretmek mümkündür. Devlet başkanının güç ve yetkilerindeki artış, bu makama oturacak kişilerin "nasıl belirlenmesi" gerektiği sorununu ortaya çıkarmaktadır. ${ }^{14}$ Zira Sartori’nin de belirttiği üzere seçim sistemi tercihi, bilhassa ciddi kutuplaşmanın olduğu bir ülkede siyasi sistemi şekillendirmede kullanılabilecek en güçlü maniveladır. Bu sebeple özenli bir şekilde uzlaşı ile bu yöntem belirlenmeli ve kutuplaşmaya olanak tanınmamalıdır. ${ }^{15}$

Nitekim devlet başkanının halk tarafından seçilme yöneliminin yaygınlaşması verilerden de kendini göstermektedir. Dünya'da 200'den fazla

12 Nitekim ABD'de zaman zaman kuvvetlerin birbirinin önüne geçme mücadelesi yaşanmış ve 1900-1937 yılları arasında Yüksek Mahkeme'nin aktif rol aldığı sürece “yargıçlar hükümeti” isimlendirmesi yapılmıştır. Yusuf Şevki Hakyemez, "Anayasa Mahkemelerinin Geleneksel İşlevi Bağlamında Günümüzde Ortaya Çıkan İki Sorun: Yerindelik Denetimi Tartışmaları ve Ulusalüstü Örgüte Üye Devletlerdeki Anayasa Yargısının Konu Bakımından Sınırlandırılması", 2007, 24, Anayasa Yargısı, s. 545. Sonraki dönemde Başkanların kararname yetkisini aktif kullanımı ile bu güç dengesi yürütme lehine bozulmuştur.

13 Bülent Tanör/ Necmi Yüzbaşığlu, 1982 Anayasasına göre Türk Anayasa Hukuku, 20. Bask1, Beta, 2020, s. 339. Özbudun, s. 299.

14 Devlet başkanının güçlendirilmesi eğiliminin hız kazanması, hükümet sistemleri tasniflerini de zorlaştıran bir husus olagelmiștir. Başkanlık ve yarı başkanlık sistemlerinde devlet başkanının halk tarafından seçilmesi bir zorunluluktur. Buna karşın klasik parlamenter sistemlerde, devlet başkanının sorumsuz ve yetkisiz olması, devleti temsil ve organlar arasında arabulucu rolü üstlenmesi sebebiyle irsi usuller ile veya meclis tarafindan seçildiği bilinmektedir. Buna karşın, parlamenter cumhuriyet ile yönetilen pek çok ülkenin, devlet başkanının seçim usulünü değiştirmeye başladığı görülmüş ve meclisler seçim görevini halka devretmişlerdir. Örneğin İrlanda, Avusturya, Portekiz, İzlanda bu ülkelerin başında gelmekte olup literatürde bu ülkeler parlamenter sistem (Bkz: Özbudun, s. 318; Tanör/ Yüzbaşığlu, s. 340.) olarak görülse de başkanlı parlamenter sistem isminin de zikredilmeye başlandığı görülmektedir. (Bkz: Şule Özsoy Boyunsuz, Başkanlı Parlamenter Sistem, On İki Levha, 2014.) Böylece günümüzde, parlamenter cumhuriyetler için yapılan "devlet başkanı meclis tarafından seçilir" ifadesi geçerliliğini korusa da pek çok istisnayı ihtiva eden bir yargı haline gelmiştir.

15 Giovanni Sartori, "Political Development and Political Engineering", in J.D. Montgomery, A.O. Hirschman, (Eds.) Public Policy, Harvard University Press, 1968, s. 261-298. 
ülke verileri incelendiğinde 108 ülkenin devlet başkanının halk tarafından seçildiği görülmektedir. ${ }^{16}$ Dahası, devlet başkanı halk tarafından seçilen Kuzey Kıbrıs Türk Cumhuriyeti, Filistin, Çin Cumhuriyeti (Tayvan), Abhazya Cumhuriyeti, Somaliland, Güney Osetya, Transdinyester gibi Birleşmiş Milletlere (BM) henüz üye olamamış devletler de ilave edildiğinde bu sayının daha da arttığı görülmektedir. Seçimlerin yapılmadığı diktatörlükler ve monarşi ile yönetilen 58 ülke de hesaba katıldığında, dünyadaki ülkelerin büyük çoğunluğunda devlet başkanının halk tarafından seçildiği çıkarımı rahatlikla yapilacaktır.

Önemi ve yetkileri artan devlet başkanlığı makamına oturacak kişinin seçiminin çoğu ülkede halka bırakılması, bu belirlemenin hangi sistem ile hangi esaslar üzerine inşa edilmesi gerektiği hususuna dikkat çekilmesini sağlamıştır. Bu noktada uygulanan pratiğin fazlalı̆̆ı göze çarpmaktadır. Seçim sisteminin belirlenmesinde ülkelerin, kendi siyasi tarih ve kültürüne ve ülke gerçeklerine göre bir uyarlamaya gittiği görülmektedir. ${ }^{17}$

$\mathrm{Bu}$ çalışmada, devlet başkanının halk tarafından seçiminde hangi sistemlerin uygulandığı tespit edilecektir. BM'ye üye olan tüm ülkeler üzerinden yapılacak incelemeler ile uygulanan seçim yöntemlerinin tasnifi yapılacaktır. Seçim yöntemleri hakkında zikredilen değerlendirmelere dayanak olması veya ilgili konu için açıklayıcı olması açısından önemli noktalarda bazı devlet başkanlığı seçim sonuçları verilecektir. Uygulanmakta olan seçim sistemleri, temel olarak iki ana başlık altında tasnif edilecektir. Bu tasnifte seçimlerin tek turda bitip bitmediği esas alınacaktır. Son olarak, iki ana başlık altında tasnifi yapılan seçim sistemlerini uygulayan ülkelerden gözlemlenen ilave seçim şartları irdelenecektir. Seçilecek kişinin meşruiyetini artırmak veya çoğulculuğu sağlamak gibi saiklerle getirilen bu şartlar, verilecek seçim sonuçları ile irdelenecektir.

16 Belirtilen sayının tespitinde her ülkenin resmi anayasası detaylıca incelenmiştir. Ancak pek çok ülkenin anayasasının İngilizceye resmi tercümesi olmadığından dolayı "https:// www.constituteproject.org/constitutions?lang=en" sitesinden istifade edilmiştir. Ancak bu sitedeki anayasaların başkaca kaynaklardan güncel olup olmadığı teyit edilmiştir.

17 İlerleyen başlıklarda görüleceği üzere her ülke, kendi gerçekleri özelinde, içinde bulunduğu şartlara göre devlet başkanının nasıl seçileceğini belirlemiştir. Kimi ülkelerde devlet başkanı seçimleri sancılı bir süreci beraberinde getirdiği için tercih edilen sistem değiştirilmiş ve tek turda biten basit çoğunluk sistemi benimsenmiştir. Kimi etnik veya dini olarak bölünmüş ülkelerde ise devlet başkanı seçiminde bir sıra öngörülmüş ve sıralı etnik/dini adaylık benimsenmiştir. 


\section{Tek Turda Biten Seçim Sistemleri}

\section{A. Basit Çoğunluk Sistemi}

Devlet başkanının seçilebilmesi için mutlak çoğunluğa ulaşmanın şart olmadığı, sadece seçimi en önde tamamlamanın gerektiği seçim sistemine basit çoğunluk sistemi denilmektedir. Devlet başkanının seçiminde 22 ülkenin ${ }^{18}$ bu sistemi uyguladığ1 görülmektedir. ${ }^{19}$ Basit çoğunluk sistemi tek turda bitecek şekilde kurgulanmıştır. Ancak bunun üç istisnası bulunmaktadır. Gambia’da ilk turda en fazla oy alan aday devlet başkanı olmaktadır. Ancak iki adayın eşit oy ile en fazla oyu alarak birinci olması halinde bu iki aday arasında ikinci tur seçimleri yapılmaktadır. Güney Kore ve Filipinler'de ise benzer şekilde basit çoğunluk ile devlet başkanları seçilmektedir. Ancak yapılan seçimde eşit oy ile iki tane birincinin çıkması halinde ikinci tur seçimleri mecliste yapılmaktadır. ${ }^{20} \mathrm{Bu}$ üç ülkede, gerçekleşmesi imkânsıza yakın olan ikinci tur ihtimali matematiksel olarak mümkün olsa da hayatın olağan akışı içerisinde bir değerlendirme ile bu ülkelerdeki sistemi tek turlu basit çoğunluk başlığ1 altında tasnif etmek uygun görülmüştür.

Her seçim sisteminde olduğu gibi basit çoğunluk sisteminin de birtakım olumlu ve olumsuz yanları mevcuttur. Olumlu yanlarının başında, seçmenlerin

18 Burada ve ilerleyen başlıklarda incelenecek olan seçim sistemlerini benimseyen ülkelerin sayıları, ülke anayasaları incelenerek belirlenmiştir. İlgili seçim sistemini benimseyen ülkelerin sadece sayısı veya ismi verilerek geçiştirmek yerine; belirlenen bu ülkelerin anayasalarından ilgili hükümlerin dipnotta gösterilmesi tercih edilmiştir. Bu durum dipnotların bir miktar genişlemesi ile sonuçlanmıştır. Anayasalara yapılan bu atıfların, ileriki çalışmalara 1şık tutması amaçlanmış ve isteyen araştırmacıların ülkelerdeki değişimleri kolaylıkla gözlemleyebilmelerine ve belirtilen sayıları güncellemelerine olanak sağlanmak istenmiştir. Basit çoğunluk sistemini benimseyen ülkeler: Angola Anayasas1, 2010, m. 109/1; Bosna Hersek Anayasas1, 1995, m.5/1; Demokratik Kongo Cumhuriyeti Anayasas1, 2005, m. 71; Ekvator Ginesi Anayasas1, 1991, m. 33/1; Filipinler Anayasas1, 1987, m.7/4,5; Gabon Anayasas1, 1991, m. 9/2; Gambia Anayasas1, 1996, m. 48/3; Güney Sudan Anayasas1, 2011, m. 97/1; Güney Kore Anayasas1, 1948, m. 67/1,2,3; Honduras Anayasas1, 1982, m. 236/1; İzlanda Anayasas1, 1944, m. 5/1; Kamerun Anayasas1, 1972, m. 6/1; Kiribati Anayasas1, 1979, m. 32; Malavi Anayasas1, 1994, m. 80/2; Meksika Anayasas1, 1917, m. 81/1; Panama Anayasas1, 1972, m. 177; Paraguay Anayasas1, 1993, m. 230; Peru Anayasas1, 1993, m. 111/1,2; Ruanda Anayasas1, 2003, m. 100/2; Singapur Anayasas1, 1963, m. 19; Togo Anayasas1, 1992, m. 60/1,2; Venezüella Anayasas1, 1999, m. 228.

19 Esasen bir sonraki başlıkta anlatılacak olan devredilebilir oy sistemini kullanan İrlanda ve Sri Lanka'da da basit çoğunluk sistemi uygulanmaktadır. Ancak bu ülkelerdeki sistemin, kendine has hesaplama yöntemleri olması sebebiyle ayrı bir başlık altında incelenmesi daha doğru görülmüş ve yukarıdaki verilen sayı içerisinde bu iki ülke zikredilmemiştir.

20 Filipinler Anayasas1, 1987, m.7/4,5; Gambia Anayasas1, 1996, m. 48/3; Güney Kore Anayasas1, 1948, m. 67/1,2,3. 
kullandığı oyun neticesini doğrudan öngörebilmesi gelmektedir. Bir diğer ifade ile seçmenler, oy verdikleri adayların, seçimde birinci gelmesi halinde ek bir işlem veya şarta gerek kalmadan seçileceğinin farkında olmaktadır. $\mathrm{Bu}$ seçim sisteminde seçmenler, devredilebilir oy sisteminde olduğu gibi oy vermiş oldukları adayın mutlak çoğunluğu elde edememesi halinde, oy pusulasında ikinci bir aday tercihinde bulunmak zorunda kalmamaktadır. Aynı şekilde iki turda bitebilen seçim sistemlerindeki gibi ikinci turda istemediği adaylara oy vermek zorunda da kalmamaktadır. Ayrıca bu seçim sistemi ile seçimlerin ilk turda bitmesi gereği oldukça hararetli ve gergin sürebilecek bir ikinci tur ihtimali ile karşılaşılmamaktadır. Bir diğer olumlu yan olarak, oldukça masraflı olan seçim sürecinin tekrarı yaşanmadığı da zikredilebilir. ${ }^{21}$

Öte yandan basit çoğunluk sisteminin birtakım olumsuz etkileri de mevcuttur. Devlet başkanları özellikle başkanlık ve yarı başkanlık sistemine sahip ülkelerde geniş yetkiler ile donatılmıştır. Önemli yetkileri haiz bir makama seçilecek kişinin mümkün olabilen en geniş kabul ile göreve gelmesi beklenmelidir. Ancak basit çoğunluk sisteminde devlet başkanı, adi çoğunluk ile seçimi kazanabilmektedir. Basit çoğunluk ile bir makama sahip olabilme yoğun eleştirilere uğramış bir formülasyondur. Nitekim Sir Arthur Lewis, "çoğulcu bir toplumda demokrasi ideasını öldürmenin en emin yolu, AngloAmerikan seçim sistemini (basit çoğunluğu elde eden her şeyi kazanır/first past the post) benimsemektir" 22 diyerek bir makam1 "elde etmenin" bu denli kolay olmaması gerektiğini ortaya koymaktadır. Örneğin 1987 Güney Kore devlet başkanlığı seçiminde Roh Tae-woo \%35,9 oy oranı ile; 2006 Meksika devlet başkanlığ 1 seçiminde Felipe Calderon \%35,9 oy oranı ile; 2011 Singapur devlet başkanlığ 1 seçiminde Tony Tan Keng Yam \%35,2 oy oranı ile seçimi kazanmıştır. Filipinler'de ise oldukça düşük bir oran olan \%23,58

21 Adem Abebe/ Elliot Bulmer, Electing Presidents in Presidential and Semi-Presidential Democracies, IDEA, 2019, s. 18; Seçimlerin maliyeti ile alakalı birkaç örnek vermek yukarıda zikredilen yargının değerlendirilmesi için faydalı olacaktır. Örneğin, Türkiye'de 2018 y1lında yapılan seçimler için Yüksek Seçim Kurulu'na, Bütçe Kanununa göre tahsis edilmiş ödeneğin 258 milyon 768 bin TL olduğu görülmektedir. Elbette bu miktarın içerisinde Kurul'un seçim olmadığı yıllarda aldığı rutin bir miktarın da olduğu unutulmamalıdır. Bkz. 7066 Sayılı 2018 Yılı Merkezi Yönetim Bütçe Kanunu, 2017; Benzer şekilde Ukrayna'da 2019 devlet başkanlığı seçimi için 2,3 milyar Ukrayna Grivnası (yaklaşık 663 milyon TL) harcanmıştır. Bkz: Sofia Kochmar-Tymoshenko, Ukraine's heated presidential campaign most expensive ever, 2019, <euromaidanpress.com/2019/03/28/ukraines-heatedpresidential-campaign-most-expensive-ever/> Erişim Tarihi 18 Nisan 2021.

22 W. Arthur Lewis, Politics in West Africa, Oxford University Press, 1965, s. 71. 
ile Fidel V. Ramos 1992 yılında Devlet Başkanı olmuştur. ${ }^{23}$ Bu kişilerin almış oldukları oy oranları, tüm dünyada olduğu gibi seçime katılanlar üzerinden hesaplanmaktadır. Buna rağmen oldukça düşük bir oran ile seçildikleri görülmektedir. Oy oranlarının seçime katılanlar üzerinden değil de kayıtlı seçmenler üzerinden yapılması halinde elde edilen oranların çok daha düşük olacağı da ayrı bir gerçektir.

Basit çoğunluk ile seçilmek, seçilen kişinin meşruiyetini derinden etkileyecek bir husustur. Bir diğer ifade ile düşük bir oran ile seçilen devlet başkanının halk nezdinde olan meşruiyetinde azalma kaçınılmaz olacaktır. ${ }^{24}$ Bir toplum sözleşmesi olarak addedilen anayasadaki kurallara göre seçilen devlet başkanının hukuki meşruiyeti hususunda elbette ki bir tartışma yoktur. Ancak meşruiyetin toplumsal manada da elde edilmesi önemlidir. Bunu elde etmenin yollarının başında, devlet başkanının kapsayıcı politikalar icra etmesi ve söylemleriyle toplum nezdinde kendine duyulan aidiyeti sağlaması gelmektedir. Bu göreve geldikten sonra elde edilecek bir sosyolojik meşruiyettir. Bir de göreve gelirken elde edilmesi gereken toplumsal meşruiyet bulunmaktadır. Bu noktada devlet başkanının toplumun çoğunluğu tarafindan bu göreve getirilmesinin toplum nezdindeki meşruiyeti artırıcı bir etkisi olduğunu zikretmek gerekmektedir. Sayılar ile elde edilen toplumsal meşruiyetin artırılması, devlet başkanının devlet kurumları arasında, bilhassa yine seçimle göreve gelen yasama organı ile olan ilişkilerde, elini kuvvetlendirecek bir husus olduğunu vurgulamak gerekmektedir. Devlet başkanının almış olduğu oy yüzdesinin fazlalığı, kurumlar arası çekişmelerde

${ }^{23} \mathrm{Bu}$ çalışmada zikredilen ifadeler, yargılar, yorumlar ve çıkarımlar seçim sonuçları ile desteklenmek istenmiştir. Bu sebeple seçim sonuçlarında, öncelikle ülkelerin "seçim kurullarının" resmi sitelerinden istifade edilmiştir. Buralarda ulaşılamayan veriler, akademik çalışmalardan teyit edilerek atıf yapılmıştır. Verilere burada da ulaşılamadığında ise seçim sonuçlarını arşivleyen birtakım sitelerden istifade edilmiş, ancak bu veriler ayrıca uluslararası ajansların yapmış olduğu haberlerden teyit edilmiştir. Güney Kore, Meksika, Singapur ve Filipinler'deki seçim verileri için Bkz: Aurel Croissant, "Electoral Politics in South Korea", in Aurel Croissant, (Ed.) Electoral Politics in Southeast and East Asia, Friedrich-Ebert-Stiftung, 2002, s. 266; Instituto Nacional Electoral Mexicali, Estadísticas y Resultados Electorales, <portalanterior.ine.mx/archivos3/portal/historico/contenido/ Elecciones/> Erişim Tarihi 18 Nisan 2021; Singapoure Elections Department, Presidential Election Results, <eld.gov.sg/elections_past_results_presidential.html\#Y2011> Erişim Tarihi 18 Nisan 2021; Julio Teehankee, "Electoral Politics in the Philippines", in Aurel Croissant, (Ed.) Electoral Politics in Southeast and East Asia, Friedrich-Ebert-Stiftung, 2002, s. 167.

24 Matthew Soberg Shugart/ Rein Taagepera, "Plurality versus Majority Election of Presidents: A Proposal for a "Double Complement Rule", 1994, 27(3), Comparative Political Studies, s. 333. 
zikredilebilecek bir argüman olarak düşünülmelidir. Nitekim Linz, başkanlık sistemlerinde halk oyu ile seçilen meclisin mi yoksa halk oyu ile seçilse dahi meclis desteğinden yoksun kalan devlet başkanının mı daha fazla demokratik meşruiyete sahip kabul edileceğini irdelemiştir. ${ }^{25}$ Devlet başkanının seçimlerde elde ettiği sayısal güç, bu rekabette önem arz etmektedir. Linz'in de vurguladığ 1 bu çekişme özellikle Latin Amerika ülkelerinde yaşanmakta ve ordunun arabulucu rolü ile "postallı demokrasiyi" ${ }^{26}$ getirmesi ile sonuçlanabilmektedir. Bu noktada denilebilir ki bu seçim sisteminde, ikinci tur yapılsa idi daha geniş bir halk kitlesi tarafından desteklenecek bir adayın seçimi kazanmasına imkân verilmemekte; toplum nezdinde \%50'nin altında kalan bir destek ile makama sahip olunabilmektedir.

Basit çoğunluk sisteminin bir diğer olumsuz yanı ise Shugart ve Taagepera'nın da belirttiği üzere, bu sistemde daha az adayın seçime katıldığ 1 görülmektedir. Eğer mevcut devlet başkanı bir kez daha aday olmuş ise seçim için başvuran aday sayısında daha da ciddi bir düşüş göze çarpmaktadır. ${ }^{27}$ Mutlak çoğunluk sistemi başlığ 1 altında da zikredileceği üzere iki turdan oluşan seçim yarışlarının ilk turunda toplumdaki tüm kesimler bir çekinceye kapılmadan aday olmakta ve aldıkları oy oranları üzerinden ikinci tur için bir pazarlık kozu elde etmek istemektedirler. Ancak tek turlu basit çoğunlukta bu tablo ile genellikle karşılaşılmamaktadır.

Basit çoğunluk sistemi ile bir ülkede bulunan dini, etnik veya siyasi azınlıkların, seçimlerde etkinliğinin az olacağ 1 da değinilmesi gereken bir diğer husustur. ${ }^{28}$ Her ne kadar bu ifadenin meclis seçimleri için kullandığ 1 yaygın görülse de zikredilen bu yargının Lijphart tarafından devlet başkanlığ seçimi için de geçerli olduğu özellikle vurgulanmaktadır. ${ }^{29}$ Gerçekten de toplumda belirli bir çoğunluğa sahip olan kesimlerin, basit çoğunluk sistemi

25 Juan J. Linz, "Perils of Presidentialism", 1990, 1(1), Journal of Democracy, s. 53-64.

26 Postallı demokrasi, demokrasiye balans ayarı verme bahanesi ile askeri müdahalenin yapıldığı ülkelerde; ordunun, demokrasinin bekçisi gibi gözükmesi için sözde seçimler yapması ve siyaseti tekelinde tuttuğu dönemlerde yaşanan "sözde demokratik düzeni" ifade etmek için kullanılan ve ironi içeren bir kavramdır. Bkz. Abdurrahman Tekin/ Ömer Temel, "Political and Constitutional Developments in Tunisia and Egypt in the aftermath of the Arab Spring”, 2019, 10(19), Law \& Justice Review, s. 193.

27 Shugart/ Taagepera, s. 333.

28 Abebe/ Bulmer, s. 18-19.

29 Arend Lijphart, "The Alternative Vote: A Realistic Alternative for South Africa?", 1991, 18(2), Politikon, s. 92; Arend Lijphart, Patterns of Democracy, 2. Bask1, Yale University Press, 2012, s. 142. 
sayesinde sürekli zaferi ile sonuçlanan seçimler, seçmenlerde hoşnutsuzluğa sebep olma potansiyelini beraberinde getirmektedir. Seçimlerin ilk turunda kazanamayarak elenen, ancak ikinci turda en çok oyu alan iki aday ile ittifak masasında kendine yer bulabilecek azınlıklar, basit çoğunluk sisteminde bu denli güçlü bir rol oynayamamaktadır. Ayrıca seçimin tek turda bitmesi ve mutlak çoğunluğun aranmaması, seçimde yarışacak adayların geniş kitlelere ulaşma çabası ile merkeze yaklaşması yerine, merkezden uzaklaşmasına veya bulundukları uçlarda kalmalarına yol açabilmektedir.

\section{B. Devredilebilir Oy Sistemi}

Devredilebilir oy sisteminde seçimler tek turda sona ermektedir. İrlanda ve Sri Lanka'da uygulanmakta olan bu sistemde seçmenler, oy pusulasındaki adaylar içerisinden bir sıralama yapmak zorundadır. Seçmenler, aday tercihlerinin sıralamasını yaparak tek bir pusula üzerinden oylarını kullanmaktadırlar.

Oyların sayımına geçildiğinde ise temelde iki farklı yöntemin varlığ göze çarpmaktadır. İrlanda'da uygulanmakta olan yöntem şu şekilde işlemektedir: ${ }^{30}$ Seçmenlerin birinci tercihleri üzerinden sayım tamamlanmakta ve kullanılan oyların yarısından bir fazlasını alan aday olup olmadığ 1 kontrol edilmektedir. Eğer hiçbir aday bu orana ulaşamadıysa, son sıradaki adaya verilmiş olan oyların diğer adaylara dağıtımı yapılacak şekilde sayım işlemine devam edilmektedir. Bir diğer ifade ile seçimde sonuncu olan adaya oy veren seçmenlerin "ikinci tercihleri” dağıtılmakta ve bu adaylar elenmektedir. Eğer bu dağıtım sonunda yine hiçbir aday mutlak çoğunluğu sağlayamadıysa bu işlem, seçimde sondan ikinci olan adayın oylarının dağıtımı ile devam etmektedir. Bu şekilde bir adayın mutlak çoğunluğa ulaşacağı ana kadar "veya" en son iki aday kalana kadar seçmenlerin ikinci tercihlerinin dağıtılması ile devlet başkanı belirlenmektedir. İrlanda'da 1990 yılında yapılan seçimde, seçimi \%38,9 oy ile "ikinci sırada bitiren” Mary Robinson, son sıradaki adaya oy veren seçmenlerin ikinci tercihlerinin dağıtılması sonucu seçimi \%44,1 ile birinci surada bitiren Brian Lenihan'ın önüne geçmiş ve \%51,9 oy oranı ile Devlet Başkanı olmuştur. 2018 seçimlerinde ise \%55,8 alan Michael D. Higgins, doğrudan Devlet Başkanı olarak seçilmiştir. Buna karşın Higgins, 2011 seçiminde \%39,60 oy almış ve kaybeden adaylara verilen oyların dağıtımı sonucunda oyların \%56,8'ini alarak Devlet Başkanı seçilmiştir.

30 İrlanda Anayasas1, 1937, m. 12/2,3. 
Devlet Başkanının Halk Tarafından Seçimi Yöntemleri

\begin{tabular}{|c|c|c|c|c|c|}
\hline Adaylar & $\begin{array}{c}\text { Sandıktan } \\
\text { Çıkan Oy } \\
\% \\
\end{array}$ & $\begin{array}{l}\text { Sandiktan } \\
\text { Çıkan Oy }\end{array}$ & $\begin{array}{c}1 . \\
\text { Dağıtım }\end{array}$ & $\begin{array}{c}2 . \\
\text { Dağıtım }\end{array}$ & $\begin{array}{c}3 . \\
\text { Dağıtım }\end{array}$ \\
\hline Michael D. Higgins & 39.6 & 701,101 & $\begin{array}{r}730,480 \\
+29,379\end{array}$ & $\begin{array}{r}793,128 \\
+62,648\end{array}$ & $\begin{array}{l}1,007,104 \\
+213,976\end{array}$ \\
\hline Seán Gallagher & 28.5 & 504,964 & $\begin{array}{r}529,401 \\
+24,437\end{array}$ & $\begin{array}{r}548,373 \\
+18,972\end{array}$ & $\begin{array}{r}628,114 \\
+79,741\end{array}$ \\
\hline Martin McGuinness & 13,7 & 243,030 & $\begin{array}{c}252,611 \\
+9,581\end{array}$ & $\begin{array}{r}265,196 \\
+12,585\end{array}$ & $\begin{array}{c}-265,196 \\
\text { Elendi }\end{array}$ \\
\hline Gay Mitchell & 6,4 & 113,321 & $\begin{array}{r}127,357 \\
+14,036\end{array}$ & $\begin{array}{r}136,309 \\
+12,585\end{array}$ & $\begin{array}{c}-136,309 \\
\text { Elendi }\end{array}$ \\
\hline David Norris & 6,2 & 109,469 & $\begin{array}{c}116,526 \\
+7,057\end{array}$ & $\begin{array}{c}-116,526 \\
\text { Elendi }\end{array}$ & \\
\hline Dana R. Scallon & 2,9 & 51,220 & $\begin{array}{c}-51,220 \\
\text { Elendi }\end{array}$ & & \\
\hline Mary Davis & 2,7 & 48,657 & $\begin{array}{c}-48,657 \\
\text { Elendi }\end{array}$ & & \\
\hline
\end{tabular}

Tablo 1: 2011 Irlanda Devlet Başkanlı̆̆ Seçimi. ${ }^{31}$

Sri Lanka'da ise seçime üç aday katıllyorsa seçmenlerin iki, üçten fazla aday katılıyorsa seçmenlerin üç adayı oy pusulalarında sıralaması istenmektedir. Seçim sonucunda kullanılan oyların yarısını alan bir adayın olmaması halinde, en çok oyu almış olan iki aday haricindeki adaylar seçim yarışından elenmiş olmaktadırlar. Seçim yarışından elenen adaylara verilen oy pusulalarına bakılmakta ve bu pusulalardaki ikinci tercihler en çok oyu almış iki adaya dağıtılmaktadır. Seçime üçten fazla adayın katılması durumunda, ikinci tercihlerin kimseyi mutlak çoğunluğa taşımaması halinde, elenen seçmenlerin üçüncü tercihlerine bakılmakta ve bunlar dağıtılarak seçim

31 Elections Ireland, Presidential Election 27 October 2011, <electionsireland.org/counts. cfm?election=2011p\&cons=194> Erişim Tarihi 18 Nisan 2021. 
nihayete erdirilmektedir. $^{32}$

Sri Lanka'da uygulanan sistem ile İrlanda'daki sistem, aynı sayısal verilerde her zaman aynı sonuçları vermemektedir. Örneğin Sri Lanka’da ilk iki aday haricindeki adaylar elenmiş sayılmaktadır. Seçimi üçüncü bitiren bir adayın, diğer seçmenlerin "genelince" ikinci tercihi olması ve en çok oyu aldığı varsayımında dahi bu kişinin devlet başkanı seçilme ihtimali bulunmamaktadır. Buna karşın İrlanda'daki usulde, son sıradaki adaydan elemeye başlayarak ikinci tercihler dağıtılmakta ve üçüncü sıradaki adayın seçimi kazanabilmesi imkân dahilinde olabilmektedir. Bu noktada, Sri Lanka' daki kaybeden adayların oylarının dağıtılmasında her zaman adil bir sonuç çıkmayacağını söylemek mümkündür.

Devredilebilir oy sisteminin her iki görünümü için şu çıkarımı yapmak mümkündür: $\mathrm{Bu}$ sistemde seçimin kazananını, kaybedenler belirle(yebil) mektedir. Bu durum, adayları merkeze yaklaştırmakta ve kutuplaşmayı azaltıcı bir etki oluşturmaktadır. Zira geçmiş seçimlerde adayların pek çok kez, kaybeden adaylara oy veren seçmenlerin ikinci oylarını alarak göreve geldiği görülmektedir. Shugart'a göre bu ihtimali göz önünde tutan adaylar, partizan tutumlarını geri çekerek daha kapsayıcı söylemler geliştirmek zorunda hissederek oy geçişlerini kolaylaştırmak istemektedir. ${ }^{33}$ Sonuç olarak adayların, daha homojen tutumlar sergilemesi sayesinde karşıt kesimlerle yakın temasta bulunduğu olumlu bir siyasi yarış atmosferi ortaya çıkmaktadır. Horiwitz de bu sistemi, yukarıda zikredilen yargılardan hareketle, bölünmüş toplumlarda istikrarı sağlamanın yegâne çözümü olarak nitelendirmektedir. ${ }^{34}$

Devredilebilir oy sisteminin bir diğer önemli yanı, bu sistemde seçmenler seçim verilerinin ilan edilmesinden önce tüm tercihlerini yapmış olmaktadır. İkinci tura sarkabilen seçim sistemlerinde, adayların ilk tur sonrası ittifak pazarlıklarına giriştiği bilinmektedir. Az bir zaman zarfi içerisinde gerçekleştirilecek olan ikinci turda adaylar, seçmenlerini yapılan ittifaklara zorlamaktadirlar. Ancak devredilebilir oy sisteminde bu tür ittifaklar dar bir zamana sıkıştırılmamaktadır. Seçim öncesine bırakılmaktadır. Seçimler

32 Sri Lanka Anayasas1, 1978, m. 94/1,2,3.

33 Matthew Soberg Shugart, "Extreme Electoral Systems and the Appeal of the MixedMember Alternative", in Matthew Soberg Shugart, Martin P., Wattenberg, (Eds.) MixedMember Electoral Systems The Best of Both Worlds?, Oxford University Press, 2001, s. 39.

34 Donald L. Horowitz, A Democratic South Africa: Constitutional Engineering in a Divided Society, University of California Press, 1991. 
başlamadan önce seçmenler ve adaylar, geniş bir zaman diliminde sakin ve makul bir şekilde ikinci alternatiflerini belirleme firsatı bulabilmektedirler.

Devredilebilir oy sistemi için şu hususun altı çizilmelidir ki, her ne kadar her iki ülkede de görülmemiş olsa da bu sistemde kazanabilmek için mutlak çoğunluğa ulaşılmasına "her zaman" gerek yoktur. İkinci tercihlerin dağıtılması sonucu bir aday yine de \%50'yi geçemeyebilir. İkinci tercihlerin genellikle elenen veya düşük oy alan adaylar arasında eridiği varsayımında seçimi kazanan kişinin mutlak çoğunluğu elde edememesi "matematiksel olarak" ${ }^{35}$ söz konusu olabilmektedir. Bu sebeple bu seçim sistemini sanılanın aksine "mutlak çoğunluk sistemi" olarak addetmemek gerekmektedir.

\section{Seçiciler Kurulu Sistemi: ABD Modeli}

Amerika Birleşik Devletleri (ABD), devlet başkanının halk tarafından seçilmesine olanak tanıyan ilk demokratik ülke olarak kabul edilmektedir. İngiltere'den bağımsızlığını elde eden eyaletler, uzun tartışmalar sonunda ortaya bir anayasa metni koymuşlardır. Bu anayasada, kuvvetlerin birbirinden ayrılı̆̆ 1 temin edilmiş ayrıca kuvvetlerin birbiri üzerinde denge ve kontrol sağlayacağı birtakım enstrümanlar getirilmiştir. Yeni kurulan anayasal nizamda devlet başkanının soyluluk esasına dayanmadan göreve geleceği, halka karşı sorumlu olacağ 1 ve belirli bir süre görev yapacağı kaleme alınmıştır. Böylece kurucu babalar olarak bilinen ABD Anayasasını hazırlayan kişiler, bir Kraldan henüz bağımsızlığını kazanarak vermiş oldukları mücadeleyi, başka bir kral doğurmayacak bir sistem kurgulayarak anlamlı hale getirmişlerdir. ${ }^{36}$

35 Örneğin İrlanda' daki 2011 seçiminde, ilk dağıtımı yapılan 99,877 oyun 84,490'1 elenmeyen adaylara gitmiştir. Her dağıtımda dağıtılan oyun bir kısmının dağıtımı gerçekleşmemiştir. Zira dağıtımı yapılan oyların bir kısmının, bir önceki dağıtımda elenen adaylara gittiği veya seçmenlerin ikinci tercihte bulunmadığı görülmüştür. Mesela, Higgins'in ikinci tercihlerden hiçbir oy almadığı varsayımında Higgins'in oyu tüm hesaplamaların sonunda yine 701,101 'de kalacak, Galagher ise ikinci tercihlerden elde ettiği oylar ile 628,114 oy almış olacağını varsayalım. Bir diğer ifade ile dağıtılan oyların genellikle elenen partilerin birbiri arasında transfer edildiğini düşünelim. Seçimin sonucundaki alınan oy hesabı, son ikiye kalan adayların elde ettiği sayı üzerinden $(1,329,215)$ yapılacak olsa Higgins yine ikinci tercihten hiçbir oy alamadığ 1 varsayımında 701,101 oy ile $\% 52,74$ oranını elde edecektir. Ancak alınan oy hesabı son ikiye kalanların elde ettiği oy üzerinden yapılmamaktadır. Oy hesabı dağıtım başlamadan önce kullanılan geçerli oylar üzerinden yapılmaktadır. Dağıtıma başlanılmadan önce seçime katılanların sayısı üzerinden $(1,771,762)$ yapılacak olan oy hesabına göre Higgins, \%39,57 ile seçimin basit çoğunluk ile galibi olacaktır. Benzer tablo Sri Lanka için de çizilebilir. Görüldüğü üzere zayıf da olsa seçimi kazanan adayın, mutlak çoğunluğa ulaşamaması mümkündür.

36 Irving R. Kaufman, "The Essence of Judicial Independence", 1980, 80(4), Colombia Law Review, s. 671. 
ABD'de kurgulanan seçim yöntemini, dönemin şartları içerisinde oldukça yenilikçi bir niteliğe sahip olarak görmek gerekmektedir. İletişim ve ulaşım araçlarının yaygın olmadığı bir dönemde doğrudan halk tarafından seçimin getireceği olumsuzluklar düşünülmüş ve seçimlerin eyaletler çapında düzenlenmesi hüküm altına alınmıştır. Şöyle ki her eyaletin Temsilciler Meclisi ve Senato'ya gönderdiği üye sayısı kadar "delege", eyalet çapında yapılan seçim ile belirlenmektedir. Dört yılda bir Kasım ayının ilk Pazartesinden sonraki Salı günü yapılacak seçim ile belirlenen bu delegeler, adaylığını ilan etmiş olan devlet başkanı ve yardımcısını ayrı ayrı belirleyip, tercihlerini kapalı zarf içerisine koyarak mühürledikten sonra Senato Başkanı'na göndermektedirler. ${ }^{37}$ Aralık ayının ikinci Çarşambasını takip eden ilk Pazartesi günü kullanılan bu oylar, Senato'da Ocak ayının altıncı günü, iki Meclis'in temsilcilerinin huzurunda zarflardan çıkarılarak sayılmakta ve delegelerin mutlak çoğunluğunu alan aday başkan olarak ilan edilmektedir. ${ }^{38}$ Delegelerin oylaması sonucunda yeterli nisaba ulaşılamadığı taktirde başkan, Temsilciler Meclisi tarafından; başkan yardımcısı ise Senato tarafından seçilmektedir. ${ }^{39}$ Benzer sistemi Güney Kore de benimsemiştir. 1972, 1979 ve 1981 yıllarında yapılan seçimlerde devlet başkanı, ülkenin çeşitli bölgelerinden seçilen ve sayıları beş bini geçebilen delegeler tarafından belirlenmekteydi. ${ }^{40}$

$\mathrm{Bu}$ haliyle seçiciler kurulu ile yapılan seçimi iki turdan oluşan bir sistem olarak görmemekteyiz. Zira iki dereceli yapılan ABD'deki seçim sisteminde günümüz şartlarında, delegelerin emredici vekalet ile bağlı olduğu kabul edilmektedir. ${ }^{41}$ Seçiciler kurulunun başkanı seçmesi eylemi günümüzde bir formaliteye dönüştüğü için seçimin, iki turdan oluşmadığı şeklinde yorum yapmak yanlış olmayacaktır. Esasen seçimler, halk tarafından delegelerin belirlenmesi ile sona ermiş olmaktadır. ${ }^{42}$ Elbette ki bu durum ilelebet bu şekilde

37 Amerika Birleşik Devletleri Anayasası, 1787, m.2/1.

38 Seçim süreci ile alakalı tüm detaylar için ABD'nin en temel kanunlardan biri olan US Code'a bak1labilir: United States Code, Title 3, 1948, <govinfo.gov/content/pkg/USCODE2019-title3/pdf/USCODE-2019-title3.pdf> Erişim Tarihi 18 Nisan 2021.

39 Amerika Birleşik Devletleri Anayasası, 1787, 12th amendment.

40 Croissant, s. 266.

${ }_{41}$ Louis Favereu, Droit Constitutionnel, Paris, Dallos, 1998, s. 584-585'den (aktaran) Gözler, s. 17.

42 Ancak XIX. yüzyıl başında iki kez delegelerin mutlak çoğunluğa ulaşamadığı görülmüştür. $\mathrm{Bu}$ dönemlerde partiler yeni gelişmeye başlamakta, aday sayısı fazla ve adaylar birbirine yakın sayıda delegeye sahip olabilmekteydiler. Örneğin 1824 yılında en fazla delegeyi kazanan iki adayın aynı partiden olduğu görülmektedir. Günümüzde sistem bir nebze 
gidecek de değildir. Gelecekte delegelerin emredici vekalet ile bağlı olmadan hareket ederek seçiciler kurulunu, "oyun değiştirici bir aktör" seviyesine taşıdığında veya delegelerin başkanı seçme işlemini tamamlayamadığı için meclislerin devreye girdiği bir gelecekte, iki dereceli olan ABD'deki seçim sistemini ayrıca iki turlu olarak da kabul etmek gerekecektir.

ABD'de iki dereceli seçim sisteminin benimsenmesi günümüzde eleştirilerin odağı haline gelmiştir. Halkın doğrudan devlet başkanını belirleyememesi hususu eleştirilen hususların başında gelmektedir. Dönemin şartları için oldukça parlak bir fikir olan delege sistemi ile delegeler, özgür iradeleri ile eyaletteki seçmenlerden aldıkları vekalet üzerine tercihlerini yapacaklardır. Esasen Anayasanın ilk yapıldığı dönemde siyasi partilerin olmaması delegeleri, tercihlerinde daha bağımsız yapmakta idi. Ancak günümüzde siyasi partilerin varlığı ve delegelerin parti düşüncesi dışına çıkamaması bir gerçek halini almıştır. ${ }^{43}$ Günümüzde seçmenler de bu durumun bilincinde olduklarından dolayı oylarını bu gerçek üzerinden hareketle kullanmaktadırlar. Günümüzde seçilen delegeler, emredici vekalet ile bağlı olup, halktan almış oldukları görev gereği adına seçildiği kitleyi temsil eden adaya oy vermektedirler. Delege sisteminin emredici vekalet ile bağlı olması gerçeğinden hareketle yapılan eleştiriler yersiz kalmaktadır. Nitekim günümüzde yazılı olmayan kurallar gereği seçilen delegenin partisinin adayı dışındaki bir adaya oy vererek seçimin kaderini değiştirdiği görülmemiştir. ${ }^{44}$ Delegenin temsil ettiği vatandaşların oylarına muhalif bir oy kullanarak "esasında seçilmesi gereken kişinin değişmesi" daha önce yaşanmadığ 1 için delege sistemini günümüz penceresinden eleştirmeyi makul görmemek gerekir. ${ }^{45}$ Buna karşın gelecekte önemli sayıda delegenin

oturmuş, iki büyük parti mevcut olup her bir partinin belirlediği bir aday seçime girmekte ve delegeler emredici vekalet ile bağl1 şekilde hareket etmektedirler.

43 ABD'deki delege sisteminin hangi saikler ile getirildiği, kuruluş evresinde çıkan tartışmalar, ileriye sürülen diğer seçim metotları ve mevcut sistem hakkında daha geniş bilgi için Bkz. Paul Boudreaux, "The Electoral College and its Meager Federalism", 2004, 88(2), Marquette Law Review, s. 196-249.

44 Burada dikkat edilmesi gereken husus, seçimi kazananın değişmemesidir. Delegelerin farklı adaylara oy vermesi ile geçmişte on kez karşılaşılmıştır. Ancak hiçbirinde seçim sonuçları değişmemiştir. Favereu, s. 584'den (aktaran) Gözler, s. 17.

45 Delege sisteminin uygulanmasında bir beis görülmemesi hususunda daha fazla argüman için Bkz. Judith Best, The Case against Direct Election of the President: A Defense of the Electoral College, Ithaca, Cornell University Press, 1971. Aksi görüşler için ise Bkz: Robert M. Hardaway, The Electoral College and the Constitution: The Case for Preserving Federalism, Praeger, 1994. 
seçilecek kişinin belirlenmesinde aksi yönde hareket etmesi ile karşılaşılabilir. Böylesi bir tabloda seçmenlerin tercihleri, seçilecek kişinin belirlenmesine yansıyamayacaktır. Bu ihtimal üzerinden delege sistemini eleştirmek elbette ki mümkündür.

Buna karşın, delege sistemine eleştiri getirilecekse eğer, bu noktada argüman, temsilde adaletsiz bir seçim sisteminin varlı̆̆ 1 üzerinden yapılmalıdır. Her eyalet kendi bölgesinde seçilecek olan delegelerin seçim usulünü belirleme hakkına sahip olsa da genel eğilimin "eyalet çapında ulusal listeli çoğunluk sistemi” olduğu görülmektedir. Bu seçim sistemi ile delegelerin belirlenmesinin, temsilde adalet ile bağdaşması mümkün değildir. Örneğin 2000 yılında gerçekleştirilen ABD Başkanlık seçiminde, yaklaşık 9 milyon seçmenin bulunduğu Florida eyaletinde 537 oy fark ile 25 delegenin tamamını George Bush almış ve elde ettiği bu delege sayısı sayesinde tüm ülkeyi yönetme hakkını kazanmıştır. Dahası, söz konusu seçimde tüm eyaletlerde kullanılan oyların daha fazlasını alan Al Gore seçimi kaybetmiştir. Benzer şekilde Hillary Clinton rakibinden üç milyon daha fazla oy almasına rağmen seçimden mağlup ayrılmıştır. ${ }^{46}$ Görüldüğü üzere daha fazla oy alanın değil daha fazla delegenin kazanılması başkanı belirlemektedir. 2000 yılından bu yana görülen bu iki sonuç, delege sisteminin ciddi manada eleştirilmesine yol açmıştır. ${ }^{47}$ Çoğunluk sistemi gereği eyaletlerdeki tüm delegelerin kazanan kesime verilmesi kuralı, o eyalette seçimi kazanma ihtimali az olan adayın seçmenlerinin oy vermekten kaçınmasına da yol açabilmektedir. Nispi temsil kuralı geçerli olduğu bir durumda seçime katılım oranlarının artacağ 1 ve adayların alacağı oy oranlarının ve elde edeceği delege sayılarının değişeceği çıkarımını yapmak yanlış olmayacaktır.

Delege sistemi için getirilen bir diğer eleştiri ise eyaletlerin temsilde adil olmayan bir oranda delegeye sahip olmasından kaynaklanmaktadır. Her ne kadar eyaletlerin Temsilciler Meclisine gönderdiği üye sayıları nüfus esasına göre yapılsa da Senatoya gönderilen üye sayısında eyaletler arasında eşitlik bulunmaktadır. Bu durum da küçük eyaletlerin aşkın bir temsile kavuşmasına yol açmaktadır. ${ }^{48}$

46 Federal Election Commission, Election results, <fec.gov/introduction-campaign-finance/ election-and-voting-information/> Erişim Tarihi 18 Nisan 2021.

47 Boudreaux, s. 248-249; Alexander Keyssar, Why Do We Still Have The Electoral College?, Harvard University Press, 2020, s. 207-225.

48 Yukarıda da zikredildiği üzere bir eyaletin delege sayısı: Temsilciler Meclisi ve Senato’ya gönderdiği üye sayısı kadardır. Yukarıda zikredilen yargıyı bir örnekle desteklemek yerinde 
ABD Anayasasınca öngörülmüş olan delege sisteminden vaz geçilmesi kolay olmayacaktır. Nitekim ABD Anayasası, en zor değişen anayasalardan biri olması ile bilinmektedir. Her iki Mecliste 2/3' lük bir çoğunluğun desteğine ilaveten, eyaletlerin 3/4'ünde de söz konusu değişikliğin kabul edilmesi gerekmektedir. ${ }^{49}$ Unutulmamalıdır ki ABD siyasetini egemen olan her iki parti de mevcut sistemin getirdiği olumsuz yanlara rağmen adaylarını birbiri ardınca seçtirebilmektedir. Sistemin aksayan yanları mevcut olsa da dönem dönem her iki parti de bunlardan istifade edebilmektedir. Ayrıca doğrudan halk tarafından seçim sisteminin gelmesi ile üçüncü bir adayın yarışta etkin bir noktaya gelme ihtimalinin de artacağı unutulmamalıdır. Mevcut sistemde iki büyük partinin dışındaki adaylar güçlü de olsalar, çoğunluk sisteminin uygulandığı eyaletlerde en fazla oyu alma şansları az olduğu için delege kazanmaları mümkün olamamaktadır. Ancak ülke çapında yapılacak bir seçim kurgulandığı zaman, adayların önünde "eyalette en çok oyu alma" gibi aşılması zor bir bariyer kalmayacaktır. Bu sebeple yakın bir gelecekte bu sistemin tadilata uğrasa da değişmeyeceği öngörüsü yapılabilir.

\section{Tek Turda Bitmeyebilen Seçim Sistemleri}

Bu başlik altında seçimlerin ilk turda nihayete erdirilememe ihtimalinin olduğu sistemler izah edilecektir. Başlıklandırma yapılırken "iki turlu seçim sistemleri" ifadesinden kaçınılmıştır. Zira şartların elvermesi durumunda seçimlerin ilk turda nihayete ermesi mümkündür. İki turlu seçim sistemleri ifadesinin tercih edilmemesinin bir diğer sebebi ise bu ifadenin seçimlerin en fazla iki turdan ibaret olduğuna vurgu yapmasıdır. Ancak Nijerya'da seçimler, belli şartların gerçekleşmesi halinde üçüncü tura sarkabilmektedir. Bu sebeple tasnif dışı kalan bir ülkenin olmaması için başlıkta daha genel bir ifade tercih edilmiştir.

\section{A. Nitelikli Çoğunluk Sistemi: Sierra Leone Modeli}

Devlet başkanının seçiminde genellikle basit çoğunluk veya mutlak çoğunluğun arandığı görülmektedir. Bu noktada tek bir istisnadan bahsetmek gerekecektir. Sierra Leone'de seçimin birinci turunda seçimde kullanılan geçerli oyların \%55'inden bir fazla oyu alan kişinin devlet başkanı olacağ 1

olacaktır. Örneğin Woyaming Eyaletinde 276,765 seçmen için 3 delege; Kaliforniya'da ise 25,090,517 seçmen için 55 delege seçilmektedir. National Archives, 2020 Electoral College Results, <archives.gov/electoral-college/2020> Erişim Tarihi 18 Nisan 2021.

49 Amerika Birleşik Devletleri Anayasas1, 1787, m. 5; Örneğin, 27. Anayasa değişikliği, 202 y1l sonra söz konusu süreçler tamamlanarak yürürlüğe girebilmiştir. 
hüküm altına alınmıştır. Bunun gerçekleşmemesi durumunda ise en çok oyu alan iki adayın, ikinci turda yarışması söz konusu olacak ve bu turda en çok oyu alan kişi devlet başkanı olacaktır. ${ }^{50}$

Nitelikli çoğunluk kuralının getirilmesi ile devlet başkanı adaylarının, daha kapsayıcı politikalar icra etmesinin ve geniş kitlelerin desteği ile ilk turda seçilmesinin sağlanmaya çalışıldığı söylenebilir. Bu sayede seçilecek kişinin halk nezdindeki meşruiyetini daha da artırması sağlanabilmektedir. Ancak siyasi tıkanıklıkların yaşanmaması amacıyla, ikinci tura gelindiğinde bu oran yerine mutlak çoğunluğun arandığı görülmektedir. Bu noktada azalan nisabın belirlenmesini makul görmek gerekmektedir.

Son üç devlet başkanlığı seçiminin sadece birinde \%55 sınırının aşılarak tek turda seçimin bittiği görülmüştür. 2007 yılında birinci turda $\% 44,34$ oy alan Ernest Bai Koroma ikinci turda \%54,62 ile; 2018 y1linda birinci turda $\% 43,26$ oy alan Julius Maada Bio ikinci turda \%51,81 oy ile Devlet Başkanı seçilmişlerdir. 2012 y1lında ise Ernest Bai Koroma birinci turda \%58,65 oy ile seçilmiştir. ${ }^{51}$

\section{B. Mutlak Çoğunluk Sistemi}

Devlet başkanının seçiminde aranan nisap olarak, yaygın bir şekilde mutlak çoğunluk sisteminin benimsendiği görülmektedir. Dünya' da 75 ülkede, devlet başkanı adaylarının seçimi kazanabilmesi için en az $\% 50+1$ oy alması şart koşulmuştur. ${ }^{52}$ Mutlak çoğunluğun şart koşulduğu sistemlerin, birden

50 Sierra Leone Anayasas1, 1991, m. 42/2-e, f.

51 Sierra Leone National Election Commission, Presidential Election Results, $<$ nec.gov.sl/site/ elections_results> Erişim Tarihi 18 Nisan 2021.

52 Afganistan Anayasas1, 2004, m. 61; Avusturya Anayasas1, 1920, m. 60/1,2; Azerbaycan Anayasas1, 1995, 101/2,3; Belarus Anayasas1, 2004, m. 82/2,3; Benin Anayasas1, 1990, m. 43. Brezilya Anayasas1, 1988, m. 77/1. Bulgaristan Anayasas1, 1991, m. 93/3,4. Burkina Faso Anayasas1, 1991, m. 39/2. Burundi Anayasas1, 2018, m. 103/1,2. Cezayir Anayasas1, 2020, m. 89/2. Cibuti Anayasas1, 1992, m. 27/1,2. Çad Anayasası, 2018, m. 71/1,2,3. Çekya Anayasası, 1993, m. 56/1,2. Doğu Timor Anayasas1, 2002, m. 76/2,3,4; Dominik Cumhuriyeti Anayasas1, 2015, m. 124/1; El Salvador Anayasas1, 1983, m. 80/2. Endonezya Anayasas1, 19, m. 6A/2,3,4. Fildişi Sahilleri, 2016, m. 56/1,3,5. Finlandiya Anayasas1, 1999, m. 54/2. Fransa Anayasas1, 1958, m. 7/1. Gana Anayasas1, 1992, m. 63/3,4,5. Gine Anayasas1, 2010, m. 32/2. Gine Bissau Anayasas1, 1984, m. 64/2. Guatemala Anayasas1, 1985, m. 184/2. Güney Kıbrıs Rum Yönetimi Anayasas1, 1960, m. 39/2. Gürcistan Anayasas1, 1995, m.; Hurvatistan Anayasas1, 1991, m. 95/3. İran Anayasas1, 1979, m. 117. Kabo Verde Anayasas1, 1980, m. 121/1,2. Karadağ Anayasas1, 2007, m. 96. Kazakistan Anayasas1, 1995, m. 41/4. Kenya Anayasas1, 2010, m. 138/4,5. Kirgizistan Anayasas1, 2010, m. 62/2. Kolombiya Anayasas1, 1991, m. 190/1. Komor Anayasas1, 2018, m. 52/4. Kongo Cumhuriyeti 
fazla turda yapılacak şekilde kurgulandığı görülmektedir. Zira görece yüksek olan bu çoğunluğa ulaşılamaması ihtimali ile pek çok ülkede karşılaşılmıştır. Bilhassa birden fazla adayın seçim yarışına girmesi halinde adayların ilk turda mutlak çoğunluğu elde etme ihtimali de düşmektedir. Bu durumda en çok oyu alan iki adayın, ikinci turda tekrar yarışması şeklinde seçimler yenilenmektedir. Yapılan bu turda adaylardan birinin mutlak çoğunluğu kazanması beklenmektedir. Nijerya'da ise öngörülen şartlar çerçevesinde seçimlerin ikinci turda dahi tamamlanmama ihtimali mevcuttur. Bu durumda seçimler üçüncü tura sarkmakta ve kazanan, bu turda belirlenmektedir. ${ }^{53}$

Bu noktada, \%50'nin bir fazlası ibaresinin anlamının ülkeden ülkeye değiştiğini ve üç farklı yöntemin uygulandığını belirtmek gerekmektedir. Birinci yöntemde, kullanılan geçerli oylar üzerinden hesap yapılmaktadır. Böylece protesto oylar veya dikkatsizlik sonucu yanlış kullanılan oyların, seçim yarışındaki adayların oy oranları üzerinde bir etkisi olmamaktadır. $\mathrm{Bu}$ yöntem en yaygın kullanılan metot olarak karşımıza çıkmaktadır. Aşağıdaki yöntemlerin uygulandığ 1 ülkeler hariç tutulursa mutlak çoğunluk sisteminin uygulandığg ülkelerde geçerli oylar üzerinden hesaplama yapılmaktadır.

İkinci yöntemde, devlet başkanının daha geniş bir kitle tarafından seçilmesinin arzu edilmesi sebebiyle temel alınan \%50 oran, kayıtlı seçmenler üzerinden hesaplanmaktadır. Böylesi bir uygulama sadece Kuzey

Anayasas1, 2015, m. 67/1; Kuzey Makedonya Anayasas1, 1991, m. 81; Liberya Anayasas1, 1986, m. 83/2. Litvanya Anayasas1, 1992, m. 81/1; Madagaskar Anayasas1, 2010, m. 47/3. Maldivler Anayasas1, 2008, m. 111/1. Mali Anayasas1, 1992, m. 30/1. Misır Anayasas1, 2014, m. 143/1. Moğolistan Anayasas1, 1992, m. 31/4,5; Moritanya Anayasas1, 1991, m. 26/1. Moldova Anayasas1, 1994, 78/4. Mozambik Anayasas1, 2004, m. 148. Namibya Anayasas1, 1990, m. 28/2-b. Nijer Anayasas1, 2010, m. 48/1,3,9. Nijerya Anayasas1, 1999, m. 133, 134; Orta Afrika Cumhuriyeti Anayasas1, 2016, m. 35/1. Palau Anayasas1, 1981, m. 8/3. Polonya Anayasas1, 1997, m. 127/4,5; Portekiz Anayasas1, 1976, m. 126/1,2. Romanya Anayasas1, 1991, m. 81/2,3. Rusya Anayasas1, 1993, m. 81/1,4. Sao Tome ve Principe Anayasas1, 1975, m. 78; Senegal Anayasas1, 2001, m. 33/2,3. Seyşeller Anayasas1, 1993, Ek m. 3/5. Sirbistan Anayasas1, 2006, m. 114/1; Slovakya Anayasas1, 1992, m. 101/4,5. Slovenya Anayasas1, 1991, m. 103/2; Suriye Anayasas1, 2012, m. 86/2. Şili Anayasas1, 1980, m. 26/1,2. Tacikistan Anayasas1, 1994, m. 65/1; Tanzanya Anayasas1, 1977, m. 41/6. Tunus Anayasas1, 2014, m. 75/2. Türkiye Anayasas1, 1982, m. 101. Türkmenistan Anayasas1, 2008, m. 70/1,2. Uganda Anayasas1, 1995, m. 103/4,5. Ukrayna Anayasas1, 1996, m. 103. Uruguay Anayasas1, 1966, m. 151. Özbekistan Anayasas1, 1992, m. 90/2. Yemen Anayasas1, 1991, m. 108/1-f. Zambiya Anayasas1, 1991, m. 101/2,3. Zimbabve Anayasas1, 2013, m. 92.

53 Dünya'da devlet başkanlığı seçimlerinin üçüncü tura kalabildiği tek ülke olan Nijerya'da uygulanan sistem de mutlak çoğunluktur. Ancak Nijerya'da uygulanmakta olan sistem oldukça karmaşı "ilave şartlar" ihtiva ettiğinden dolayı, bu sistemin uygulandığı Endonezya ve Kenya'daki sistem ile birlikte aşağıda ayrı bir başlık altında irdelenecektir. 
Makedonya'da devlet başkanının seçiminin birinci turunda görülmektedir. Birinci turda adayların seçimi kazanabilmesi için kayıtlı tüm seçmenlerin \%50'sinden bir fazlasının oyunu alması şart koşulmuştur. ${ }^{54}$ Nitekim 2014 yılında yapılan Kuzey Makedonya Devlet Başkanlığı seçiminde Gjorge Ivanov, kullanılan oyların \%51,67'sini almış olmasına rağmen seçimler ikinci tura kalmıştır. ${ }^{55}$

Seçimi kazanabilmek için aranan \%50 nisabının hesaplanmasında kullanılan üçüncü yöntemde, "kullanılan oylar" üzerinden hesaplamalar yapılmaktadır. Bir diğer ifade ile geçersiz ve boş atılan oylar da \%50'nin hesaplamasında kullanılmaktadır. Kuzey Makedonya ve Moğolistan'da ikinci turda bu sistemin uygulandığ görülmektedir. ${ }^{56} \mathrm{Bu}$ ülkelerde ilk turda belirtilen nisaba ulaşan bir aday çıkmadığı takdirde, ikinci tur seçimleri yapılmakta ve bu turda kullanılan oyların \%50'sinden bir fazlasını alan aday seçimi kazanmaktadır. Son tura iki adayın kaldığı seçimde, geçersiz ve boş oyların da bulunması söz konusu olduğundan dolayı bir adayın mutlak çoğunluğa ulaşamaması söz konusu olabilecektir. Bu durumda da seçimlerin yeniden yapılması hüküm altına alınmıştır. Böylece aranan nisap zorlaştırılmış ve seçilecek kişinin daha geniş bir uzlaşıyla seçilmesi teşvik edilmiştir. Nitekim Moğolistan'da 2017 yılında yapılan devlet başkanlığı seçiminin ikinci turunda Khaltmaagiin Battulga, rakibinden oldukça yüksek oy almış olmasına rağmen, sistem gereği geçersiz ve boş oyların da sayıma dahil edilmesi kuralı sebebiyle az bir farkla devlet başkanı seçilebilmiştir. Geçersiz oyların, toplam oylar içindeki yüzdesinin \%8'i aştı̆g bu seçimde Battulga, \%50,6 ile seçilebilmiştir. Esasen geçerli oylar üzerinden hesap yapılınca Battulga'nın $\% 55,15$ ile rakibinden $\% 10$ daha fazla oy aldığı görülmektedir. ${ }^{57}$

Sırbistan'da da geçersiz ve boş oylar \%50'nin tespit edilmesinde hesaba katılmaktadır. Ancak Moğolistan ve Kuzey Makedonya'nın aksine ikinci turda yarışan iki adaydan hiçbirinin \%50'ye ulaşamaması durumunda seçimler iptal edilerek yenilenmemektedir. ${ }^{58} 2012$ yılında gerçekleşen devlet başkanlığ 1

54 Kuzey Makedonya Anayasas1, 1991, m. 81.

55 İkinci turda, kullanılan oyların \%55,27’ünü alan Ivanov seçilmiştir. Election Guide, Republic of North Macedonia Electıon for President, <electionguide.org/elections/id/2790/> Erişim Tarihi 18 Nisan 2021.

56 Moğolistan Anayasası, 1992, m. 31/4,5; Kuzey Makedonya Anayasası, 1991, m. 81.

57 Bkz. General Election Committee of Mongolia, Results of the Second Vote of the Presidential Election of Mongolia 2017, <gec.gov.mn/blog/2188> Erişim Tarihi 18 Nisan 2021.

58 Sirbistan Anayasas1, 2006, m. 114/1. 
seçiminin ikinci turunda Tomislav Nikolic her ne kadar geçerli oyların $\% 51,15$ 'ini almış olsa da, sistem gereği geçersiz oylar üzerinden hesaplama yapılmış ve Nikolic \%49,54 ile Devlet Başkanı seçilmiştir. ${ }^{59}$

Mutlak çoğunluk sisteminin birtakım olumlu ve olumsuz yanları mevcuttur. Bu sistemin en önemli olumlu yanı, seçilecek kişinin basit çoğunluk yerine, seçmenlerin en az yarısının oluru ile göreve gelmesinin gerekmesidir. Geniş bir kabul ile devlet başkanının seçilmesinin sağlandığı bu sistemde, göreve gelecek kişinin basit çoğunluk sisteminde karşılaşma ihtimali olan meşruiyet sorunları daha az yaşanacaktır. ${ }^{60}$ Zira basit çoğunluk sisteminde, mutlak çoğunluğun oldukça altında alınan oy oranları ile göreve başlanması söz konusu olabilmektedir.

Mutlak çoğunluk sisteminde, seçimlerin basit çoğunluk ile bitmesi mümkün olmadığından dolayı yarışın ikinci tura kalma ihtimali bulunmaktadır. $\mathrm{Bu}$ durum, seçime katılan adayların sayısında bir artışın yaşanmasına yol açabilen bir husustur. ${ }^{61}$ Ayrıca bu sistemde ilk tur, sayıca az olan etnik veya dini kesimlere veya siyasi yapılara, seçmen nezdindeki gücünü ikinci tura kalacak olan adaylara gösterme firsatı sunmaktadır. İlk turda kaybedenler, elde ettikleri oy oranları ile ikinci tura kalan adaylarla adil bir pazarlık yapabilme imkanına kavuşabilmektedir. Böylece bu kesimlerin, ikinci turda yaşanacak muhtemel koalisyon görüşmelerine daha güçlü katılımı mümkün olabilmektedir.

Mutlak çoğunluk sisteminin bir diğer önemli yanı ise seçimlerin ilk turda tamamlanmaması halinde seçmenler, ikinci tura kalan adaylar arasından ikinci bir tercihte bulunma imkanına kavuşmaktadırlar. Böylece seçimin ikinci turda galibini, ilk turda "kaybedenler" belirlemektedir. Bu da çoğulculuğu sağlama açısından oldukça önemli bir firsattır. Hatta seçimlerin ilk turunda ikinci sırada olan adayların, ittifaklar ile ikinci turda kazanma ihtimali dahi bulunmaktadır. Böylesi bir durum, 2012 yılında yapılan Sırbistan devlet başkanlığı seçiminde görülmüş ve esasen ilk turu \%25,05 ile ikinci sırada tamamlayan Nikolic,

59 OSCE, Republic of Serbia Parliamentary and Early Presidential Elections 6 and 20 May 2012, < osce.org/files/f/documents/d/e/92509.pdf> Erişim Tarihi 18 Nisan 2021.

60 Laurent Bouton/ Gabriele Gratton, "Majority Runoff Elections: Strategic Voting and Duverger's Hypothesis", 2015, 10(2), Theoretical Economics, s. 284.

${ }^{61}$ Her ne kadar Duverger, iki turlu mutlak çoğunluk sisteminin iki büyük aday arasında yarışın geçmesi gibi bir sonucu doğuracağını zikrediyor olsa da bilhassa mevcut devlet başkanının yapılacak seçimlere katılmadığı pek çok seçim verilerinden bu yargının yanlış olduğu çıkarımı yapılmaktadır. Bkz: Shugart/ Taagepera s. 333; Mark P. Jones, "Presidential and Legislative Elections", in Erik S. Herron, Robert J. Pekkanen, Matthew S. Shugart, (Eds.) The Oxford Handbook of Electoral Systems, Oxford University Press, 2018, s. 288-291. 
ikinci turda yapılan ittifaklar neticesinde seçimi kazanmıştır.

Mutlak çoğunluk sisteminin olumsuz yanlarına bakıldığında ilk bahsedilmesi gereken husus, seçim maliyetidir. ${ }^{62}$ Bir diğer husus ise ikinci turun 2-3 hafta gibi kısa bir zaman zarfı içerisinde gerçekleşecek olması ve bu turun gerçekleşmesinden öncesi yaşanma ihtimali bulunan şiddet olayları ve kutuplaşma riskidir. Nitekim Afrika özelinde bu çekinceler bağlamında mutlak çoğunluk sisteminden vazgeçilerek basit çoğunluk sisteminin benimsendiği görülmüştür. Bu bağlamda Demokratik Kongo Cumhuriyeti, Gambia ve Togo söz konusu gerekçeler ile basit çoğunluk sistemini benimsemiştir. ${ }^{63}$

\section{C. Şartlı Basit Çoğunluk Sistemi ${ }^{64}$}

Latin Amerika ülkelerinde, basit ve mutlak çoğunluk sisteminin bir tür karma hale getirildiği bu seçim modeli yaygınlaşmaya başlamıştır. Bu seçim sisteminin özünde, ilk turda devlet başkanının mutlak çoğunluk ile seçilme zorunluluğu bulunmamaktadır. Belli şartların gerçekleşmesi halinde basit çoğunluk ile devlet başkanının ilk turda seçilmesi mümkün olmaktadır. Şartın gerçekleşmemesi durumunda ise, mutlak çoğunluk sisteminde olduğu gibi en çok oyu alan iki aday ikinci turda yarışmakta ve mutlak çoğunluğun oyunu alan aday seçimi kazanmaktadır. Seçim sisteminin isimlendirmesini de bu maksatla şartlı basit çoğunluk olarak nitelendirmek uygun görülmüştür.

$\mathrm{Bu}$ sistemin ilk turunda seçimi kazanabilmek için gereken şartları sırasıyla incelemek uygun olacaktır. Öncelikle ilk turda hangi oranın, bir kişinin şartsız koşulsuz devlet başkanı seçilmesi için yettiğinin tespit edilmesi gerekmektedir. Kosta Rika ve Nikaragua'da ilk turda devlet başkanı seçilebilmek için geçerli oyların \%40’ından fazlasını alarak birinci olma şartı aranmaktadır. Arjantin' de \%45'in bir fazlası olan bu oran; Bolivya, Haiti ve Ekvator'da ise \%50’nin bir fazlası olarak belirlenmiştir.

İlk turda söz konusu oranlara ulaşılamadığı durumda normalde ikinci turun yapılması beklenir. Ancak şartlı basit çoğunluk sisteminde, seçimin ikinci tura sarkmaması için bir şart daha getirilmiştir. Buna göre Arjantin, Ekvator ve Bolivya'da ilk turu birinci surada bitiren ancak aranan nisaba

\footnotetext{
${ }^{62}$ Seçim masrafları ile alakalı basit çoğunluk sistemi başlığı altında örnekler verilmiştir.

63 Abebe/ Bulmer, s. 21.

${ }^{64}$ Bu seçim sistemi "double complement rule" olarak ifade edilmektedir. Seçimi basit çoğunluk ile kazanarak ikinci turdan kaçınmak için iki şartın tamamlanması gerektiğinden dolayı bu isimlendirme kullanılmaktadır. Shugart/ Taagepera, s. 323.
} 
ulaşamayan aday, en az \%40 oranında oy almış ve en yakın rakibi ile arasında en az \%10 fark varsa bu aday devlet başkanı olarak ilk turda seçilmektedir. Nikaragua'da 2000 yılında yapılan reform neticesinde, ilk turda birinci olan adayın ikinci tura gerek kalmadan seçilebilmesi için en yakın rakibinden $\% 5$ fazla oy almak şartı ile $\% 35$ oy alması gerekmektedir. Haiti'de ise belirlenen fark yüksek tutulmuş ve ilk turda mutlak çoğunluğu alamayarak birinci olan adayın ikinci tura gerek kalmadan devlet başkanı olarak seçilebilmesi için en yakın rakibi ile arasında \%25 fark olması 2011 Anayasa değişikliği ile getirilmiştir. ${ }^{65}$ Bir örnek ile söz konusu şartı somutlaştırmak gerekirse; 2006 y1lında yapılan Nikaragua devlet başkanlığı seçiminde Daniel Ortega, \%38,07 oy almış ve en yakın rakibi ise $\% 28,3$ oy almıştır. Basit çoğunluk ile seçimi kazanma şartı olan \%5'lik fark sağlandığı için Ortega, Başkan olmuştur. ${ }^{66}$

Basit çoğunluk ve mutlak çoğunluk sistemi için zikredilen olumlu ve olumsuz yanlar, bu karma sistem için de aynen söylenebilir. Düşük oranlar ile göreve gelen devlet başkanının meşruiyet sorunu, seçimlerin tek turda bitirilerek masrafların ve siyasi tansiyonun azalması, ikinci turun yapilma ihtimalinin olması sebebiyle daha yüksek oy ile bir kişinin seçilebilmesi, kaybedenlerin ikinci turda kazananın belirlenmesinde rol alması gibi pek çok olumlu ve olumsuz yanı zikretmek mümkündür. Jones'un da belirttiği üzere basit çoğunluk sisteminde seçimler tek turda yapılmakta ve oldukça düşük oylar ile bir kişi seçimi kazanabilmektedir. Şartlı basit çoğunluk sistemi ile bir ara yol bulunarak belirlenen kotayı geçmek kaydıyla bir aday basit çoğunluk ile seçilebilmektedir. Jones, basit ve mutlak çoğunluk sistemine atfen bu seçim sistemini, "iki dünyanın en güzel özelliklerini alan bir sistem" ${ }^{67}$ olarak nitelendirmektedir.

\section{D. İkinci Tur Seçimlerin Mecliste Yapılması}

Günümüzde devlet başkanlığı seçiminin ikinci turunun yasama organında yapılmasının bir örneği bulunmamaktadır. Yukarıda zikredildiği üzere, Filipinler ve Güney Kore özelinde gerçekleşmesi imkansıza yakın bir ihtimal olan, seçimin ilk turunda eşit oy ile iki tane birinci çıkması durumunda devlet

\footnotetext{
65 Kosta Rika Anayasas1, 1949, m. 138/1; Nikaragua Anayasas1, 1987, m. 146/1; Arjantin Anayasası, 1853, m. 97; Bolivya Anayasas1, 2009, m. 166/1; Haiti Anayasas1, 1987, m. 134; Ekvator Anayasas1, 2008, m. 43/1.

${ }_{66}$ European Union Election Observation Mission, Presidential and Parliamentary Elections Nicaragua 2006, <aceproject.org/ero-en/regions/americas/NI/nicaragua-eo-reports/ nicaragua-presidential-and-parliamentary-elections> Erişim Tarihi 18 Nisan 2021, s. 61-62.

67 Jones, s. 287.
} 
başkanı, mecliste yapılacak oylama ile belirlenmektedir. Esasen bu iki ülkede sistem, basit çoğunluk şeklinde kurgulanmıştır. Bu ülkeler, basit çoğunluk tasnifinde değerlendirildiği için ve ikinci turun mecliste yapılma ihtimalinin azlığı sebebiyle burada incelenmemiştir. Bu başlık altında, seçimlerin ikinci tura gitme ihtimalinin hayatın olağan akışı içerisinde mevcut ve olası olduğu bir sistem irdelenecektir. Bir diğer ifade ile bu başlık altında asıl bahsedilecek olan sistem, seçimlerin ilk turunda mutlak çoğunluğa ulaşılamadığı durumda, en çok oyu alan iki aday arasından devlet başkanını meclisin belirlemesidir.

Geçmişte sadece iki ülkede uygulanan bu sistem hükümet sistemleri bakımından da şerhe muhtaç bir uygulamadır. Zira başkanlık sistemi ile yönetilen iki ülkede, Bolivya'da 2009 öncesinde ve Şili' de ise 1925-1973 yılları arasında bu sistem uygulanmıştır. Devlet başkanının seçiminin ikinci turunun mecliste yapılması sayesinde seçim masrafindan kaçınılmış olunmaktadır. Ayrıca başkanlık sistemlerinde yasama ve yürütmenin farklı siyasi ekollerin eline geçmesi sebebiyle oluşabilecek siyasi buhranların yaşanma ihtimali de azalmış olacaktır. Zira bu sistemde ikinci turda devlet başkanı, mecliste en fazla desteği alarak seçilmektedir. Böylece devlet başkanının meclis desteğinden yoksun olması gibi bir ihtimal teorik manada ortadan kalkmaktadır.

Uygulamaya bakıldığında Şili'de Meclisin, kendini bir adım geri çektiği ve 1970 seçimleri haricinde her zaman halk tarafindan en çok oyu alan kişiyi destekleyerek başkanlık koltuğunun sahibini belirlediği görülmüştür. Buna karşın Bolivya'da Meclis, king maker olarak tabir edilen kral tayin edici bir konuma oturmuştur. ${ }^{68} 1979$ yılında Meclis'te yapılan ikinci turda, 6 kez oylama yapılmış ama devlet başkanı seçebilmek için kabul edilen nisaba ulaşılamadığ 1 için erken seçim yapılmak zorunda kalınmıştır. Ayrıca, Meclis'in, iki kez halkın birinci sırada gönderdiği adayı seçmediği görülmüştür. 1985 y1lında yapılan devlet başkanlığı seçiminin birinci turunda Hugo Banzer, halktan aldığg $\% 32,83$ oy ile birinci olmasına rağmen, 157 kişilik Meclisten sadece 51 oy alarak seçimi kaybetmiştir. 1989 devlet başkanlığ 1 seçiminde $\% 25,65$ oy ile seçimi birinci sırada bitiren Gonzalo Sanchez de Lazada, Meclis’te yapılan ikinci tur oylamada 50 milletvekilinin desteği ile seçimi kaybetmiştir. ${ }^{69}$ Bolivya'da bu sistemin 2009'da kaldırılmasından önce yapılan reform ile değiştirildiği görülmüştür. Halk oylamasında mutlak çoğunluğu alan adayın çıkmaması halinde en çok oy almış iki adayın Meclis’te yapılacak ikinci tur ile

68 Abebe/ Bulmer, s. 30.

69 Lazarte R. Jorge, "Bolivia", in Dieter Nohlen, (Ed.) Elections in the Americas a Data Handbook, Vol. II, Oxford University Press, 2005, s. 151-152. 
seçilmesi öngörülmüş̧ür. Buraya kadar eski sistemle aynı olan usul, buradan sonra bambaşka bir boyut kazanmıştır. Şöyle ki en fazla oy alan iki aday Meclis'te en fazla iki kez yapılacak oylamada mutlak çoğunluğun desteğini alamadığı taktirde seçimler iptal edilecek ve başvuran tüm adayların katıldığ 1 halk oylamasında basit çoğunluk, kazanmak için yeterli görülecektir. Ancak seçimde en çok oyu alan ikinci aday ise devlet başkan yardımcısı olacaktır. Her ne kadar bugüne kadar hiç uygulanmamış olsa da bu hüküm, farklı siyasi ekollerden gelen kişilerin bir arada çalışmasını zorlaması açısından eşsiz bir uygulamadır. Bu sayede yukarıda zikredildiği üzere 1979 yılında yaşandığı gibi devlet başkanının seçilememesi ihtimali ortadan kaldırılmıştır. Unutulmamalıdır ki 1980 yılında yapılan erken seçim sonrası tekrar yaşanan devlet başkanı seçme krizi darbe ile sonuçlanmıştır. ${ }^{70}$

Bu seçim sistemini özellikle başkanlık sistemi için oldukça ilginç kabul etmek gerekmektedir. Zira başkanlık sistemlerinde genel kabul, başkanın seçiminin doğrudan halk tarafından yapılmasıdır. Meclisin, başkanın seçimine dahil edilmesinde şu temel sebebin etkin olduğu söylenebilir: Başkanın meclis desteğinden yoksun kalması sebebiyle yürütmenin etkisiz kalması ve ortaya çıkan siyasi tıkanıklıkların ülkeyi kutuplaştırması. Zira Latin Amerika ülkelerinde başkanların basit çoğunluk ile seçilmesi sebebiyle veya başkanların mutlak çoğunlukla seçilmesine rağmen farklı zamanlarda yapılan meclis seçimleri ile meclislerde sayısal kompozisyonların değişmesi nedeniyle başkanın sürekli meclis desteğinden yoksun kaldığı görülmektedir. ${ }^{71}$ Bolivya' da siyasi tıkanıklıkların bedelinin askeri darbeler ile ödenmesi riskinin de bulunması sebebiyle bu anayasal reformun hayata geçirilerek ikinci turda seçilecek başkanın, seçilmesinden önce meclis desteğini garanti etmiş olması aranmıştır. Bu bağlamda Linz, Bolivya'daki sistemi, parlamenterleştirilmiş başkanlık sisteminin vücut bulmuş hali olarak; Gamarra ise karma başkanlık sistemi olarak nitelendirmiştir. ${ }^{72}$ Böylece Meclis ile uyumlu çalışabilecek ve halk ve meclis tarafindan desteklenerek "çifte meşruiyete sahip" olan

70 Jorge, 130-133.

71 René Antonio Mayorga, "Electoral Reform in Bolivia: Origins of the Mixed-Member Proportional System", in Matthew Soberg Shugart, Martin P., Wattenberg, (Eds.) MixedMember Electoral Systems The Best of Both Worlds?, Oxford University Press, 2001, s. 198-199.

72 Juan J. Linz, "Presidential or Parliamentary Democracy: Does It Make a Difference?" in Juan J. Linz, Arturo Valenzuela, (Eds.) The Failure of Presidential Democracy, Johns Hopkins University Press, 1994, s. 86; Eduardo Gamarra "Hybrid Presidentialism and Democratization: The Case of Bolivia." in Scott Mainwaring, Matthew Soberg Shugart, (Eds.) Presidentialism and Democracy in Latin America, Cambridge University Press, 1997, s. 363-364. 
bir başkanın göreve getirilmesi sağlanmış olmaktadır, en azından temenni edilmektedir.

Başkanlık sistemlerinde meclis desteğine sahip olmanın önemi hususunu kısaca vurgulamak yerinde olacaktır. Öncelikle başkanlık sistemlerini, siyasi partilerin konumu ve özellikleri üzerinden ikiye ayırmak gerekir. ABD’deki başkanlık sistemini partiler üzerinden tanımlamak gerekirse, "serbest" iki partili başkanlık sistemi ifadesi uygun düşmektedir. Diğer ülkelerdeki başkanlık sistemini ise "disiplinli" çok partili başkanlık sistemi olarak nitelemek mümkündür. ABD’de Başkanların pek çok kez Meclis desteği olmadan görevini icra ettiği görülmüştür. Kendine muhalif bir Meclis ile etkin bir şekilde faaliyet yürüten Başkanlar, siyasi tıkanıklıkların az yaşandığı bir siyasi atmosferde görevlerini icra etmişlerdir. Örneğin George Bush 8 y1llık başkanlık süresinin son 2 yılında, Clinton 4 yılında, Obama ise 2 yılında meclis desteğinden yoksun kalmış ancak bütçenin gecikmeli geçmesi, atamaların onaylanmaması gibi ufak siyasi tıkanıklıklar hariç uyumlu bir siyaset güdülmüştür. ABD'de serbest partiler olduğu için Başkan'ın atamalarının veya meclise sunduğu reform paketlerinin rakip parti çoğunluğunca desteklendiği sıklıkla görülmüştür. ${ }^{73}$ Buna karşın çok partiden oluşan başkanlık sistemlerinde mecliste başkanın sayısal çoğunluğu sağlaması çoğu zaman kolay olmamaktadır. Disiplinli partilerin varlığı da düşünüldüğünde başkanın meclis ile sürekli çatışması kaçınılmaz hale gelebilmektedir. ${ }^{74}$ Bolivya'da sistemin kaldırıldığı 2009 yılına kadar, uzun bir süreden sonra ilk defa kutuplaşmış ve etkisiz çok partili görünümün sona erdirilmesi mümkün olabilmiş, siyasette sakinliğin pekiştirilmesi ile sürekli askeri darbeler ile yüzleşen ülkede askerin bir adım geri çekilmesini sağlamıştır. ${ }^{75}$

\section{Devlet Başkanının Seçiminde Aranan İlave Şartlar}

Devlet başkanının seçiminde uygulanan sistemler yukarıda izah edilmiştir. Bu başlık altında ise seçilecek adayın halk nezdindeki meşruiyetini

73 Örneğin Bill Clinton'ın partisi Senato'da muhalefette iken yapmış olduğu atamaların \%74'ünün Senato'dan onay aldığı görülmüştür. Atamış olduğu bakanların da Senato desteğini alması da bu yargıyı destekler niteliktedir. Clinton'un atamalarda yakaladığı oranı az görmemek gerekir. Zira Barack Obama kendi partisinin Senato'da çoğunlukta olduğu dönemde yapmış olduğu atamaların ancak \%87'sine Senato'dan onay alabilmiştir. ABD'de, serbest iki partili başkanlık sistemi olması sebebiyle Başkan'ın meclis desteğinden yoksun olması halinde çok ciddi siyasi tıkanıklıkların görülmediği hususunda daha fazla örnek ve izahat için Bkz. Tekin, s. 226, 253-254, 335-338.

74 Linz, s. 7

75 Mayorga, s. 198; Gamarra, s. 363-372. 
artıracak birtakım şartlardan bahsedilecektir. Seçim sistemlerinde getirilen ilave şartlar ile seçime katılımın artırılması; ülkede bulunan dini veya etnik kimliklerin yeteri kadar desteğini almadan devlet başkanının seçilememesi; devlet başkanının farklı dini veya etnik kimliklerden olması sağlanmaktadır. Tüm bu şartlar sayesinde daha çoğulcu bir seçim sistemi kurgulanmış olmaktadır.

\section{A. Asgari Seçime Katılım Şartı}

Devlet başkanı seçiminde getirilen şartların başında seçime katılım kotası görülmektedir. Devlet başkanının geniş bir mutabakat ile seçilerek meşruiyetinde bir sarsıntı olmamasını sağlamak için bu uygulamanın getirildiğini söylemek mümkündür. Devlet başkanının seçiminde belirlenen kotanın altında bir katılım olması durumunda seçimlerin geçersizliği ve tekrarı gündeme gelecektir. Esasen bu hüküm ile seçmenlere bir tehditte bulunulmaktadır. Şöyle ki katılımın az olması sebebiyle devlet başkanının belirlenememesi durumunda yönetimde boşluk oluşacak ve siyasi tıkanıklık riski ile karşılaşılacaktır. Ayrıca seçimlerin yenilenmesi ile oldukça maliyetli olabilen seçim masraflarına bir kez daha katlanılmak zorunda kalınacaktır.

Seçime asgari bir oranda katılım şartı getirilmesi ile seçimlerin boykot edilmesi tehlikesini de göz ardı etmemek gerekmektedir. ${ }^{76}$ Genellikle seçimi kazanma hususunda şüphesi olan kesimlerin bu yola tevessül edebileceği düşünülebilir. Seçime katılım hususunda dünya genelindeki tüm demokrasilerde gerek meclis gerek devlet başkanı gerekse de yerel seçimlerde "en az" \%10'luk bir kesimin çekimser kaldığını söylemek yanlış olmayacaktır. Hatta seçim verileri incelendiğinde özellikle Avrupa ülkelerinde seçime katılım oranlarının \%50-70 bantlarında olduğu görülmektedir. ${ }^{77}$ Seçime katılmayan seçmenlere ilaveten, devlet başkanı seçimini boykot edecek olan adaylar/partiler de eklendiğinde seçimlerin nihayete ermemesi olası bir durum olarak karşımıza çıkacaktır. Örneğin Belarus, Tacikistan, Bulgaristan'da seçimlerin geçerliliği için kayıtlı seçmenlerin yarısından bir

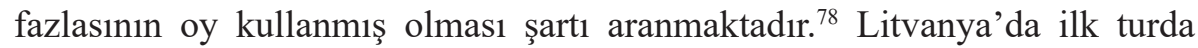
\%50'den fazla katılım aranmaktayken Kuzey Makedonya'da seçimlerin

\footnotetext{
76 Abebe/ Bulmer, s. 26.
}

77 Dünya'da seçimlerdeki katılım oranları hakkında daha fazla istatistik ve bilgi için Bkz. Abdurashid Solijonov, Voter Turnout Trends around the World, IDEA, 2016, s. 23-33.

78 Belarus Anayasas1, 2004, m. 82/1; Tacikistan Anayasası, 1994, m. 66/1; Bulgaristan Anayasas1, 1991, m. 93/3 
ikinci turunda \%40 katılım şartı aranmaktadır. ${ }^{79} \mathrm{Bu}$ hükümler 1şığında yapılan seçimlere bakıldığında yukarıda zikredilen yargının doğruluğu ortaya çıkmaktadır. Örneğin Bulgaristan'da 2016 yılında yapılan devlet başkanlığ 1 seçiminin birinci turunda $\% 56,28$, ikinci turunda ise $\% 50,44$ oranında katılım olmuştur. Seçimin ikinci turda galibi olan Rumen Radev katılan \%50,44 seçmenin \%59,37'sinin oyunu almıştır. Bir diğer ifade ile tüm seçmenlerin \%29,94'ünün oyunu almıştır. ${ }^{80}$ İkinci turda, seçimi kaybedeceğini düşünen adayın seçime katılmaması durumunda ve ona oy verecek kişilerin de oy kullanmaması durumunda, seçimi Radev'in kazanması mümkün olmayacaktı. Zira ikinci turda seçime katılım oranı, Radev'in almış olduğu oy olan \%29,94 olacaktı. Bu gibi örnekleri her ülke için vermek mümkündür. Örneğin, Kuzey Makedonya'da 2019 yılında yapılan seçimlerde ikinci turda seçime katılım oranı \% 46,70 olmuş ve seçimin galibi Stevo Pendarovski katılanların \%51,66'sının oyunu almıştır. ${ }^{81}$ Kaybeden kişinin seçimi boykot etmesi durumunda aynı yukarıdaki örnekte zikredildiği gibi seçimin yenilenmesini gerekecekti.

Sonuç olarak asgari seçime katılım şartını, seçilecek kişinin meşruiyetini artırıcı bir şart olarak görmek gerekse de sistemi tıkayabilecek ve siyasi krizleri kolaylıkla tetikleyecek bir araç olarak da addetmek yanlış olmayacaktır. ${ }^{82} \mathrm{Bu}$ noktada seçimin "sadece" ilk turunda asgari katılım kotasının belirlenmesinin yerinde olduğunu söylemek gerekecektir. Zikredildiği üzere Litvanya'da durum bu şekildedir. Her ne kadar hiç uygulanmamış olsa da Litvanya'da bu şarta bir istisna getirilerek seçimlerin ikinci tura sarkmasının önüne geçilmeye çalışılmıştır. Şöyle ki ilk turda bir aday geçerli oyların \%50'den fazlasının oyunu almasına rağmen seçime katılım oran $1 \% 50$ 'den az olduğunda, seçimin ikinci tura gitmemesi için kazanan adayın, tüm kayıtlı seçmenlerin 1/3'ünden fazla oyu almış olması aranmaktadır. ${ }^{83}$ Bu gibi hükümler ile seçime katılmayan seçmenlerin ülke siyasetini derinden etkileme gücü bir nebze kırılabilmiş olacaktır.

79 Litvanya Anayasas1, 1992, m. 81/1; Kuzey Makedonya Anayasas1, 1991, 31st amendment

80 Election Guide, Republic of Bulgaria Election for President, <electionguide.org/elections/ id/2992/> Erişim Tarihi 18 Nisan 2021.

81 Council of Europe, Observation of the Presidential Election in North Macedonia, 2019, $<$ assembly.coe.int/nw/xml/XRef/Xref-XML2HTML-en.asp?fileid=27699\&lang=en> Erișim Tarihi 18 Nisan 2021.

82 Ömer Temel, Kuzey Makedonya, in Abdurrahman Tekin, Ömer Temel, İlyas Firat Cengiz (Eds.) Osmanlı Ard1l Devletlerinin Siyasal Sistemleri, 2. Bs, Adalet, 2020, s. 379.

83 Litvanya Anayasas1, 1992, m. 81/1. 


\section{B. Sıralı Devlet Başkanlığı Sistemi: Singapur Modeli}

İdeolojik, etnik veya dini çeşitliliğin etkin olduğu kimi ülkelerde devlet başkanının, bir sıra içerisinde (hiatus-triggered model) ideolojik/etnik/dini gruplara mensup kişiler içinden seçilmesi öngörülmüştür. Sayıca çoğunlukta olan ideolojik, etnik veya dini grubun sürekli devlet başkanlık makamına sahip olmas1, bu ülkelerde siyasette tansiyonun düşmemesine yol açabilmektedir. Makam sahibinin meşruiyetini derinden etkileyebilecek bu durumun önüne geçmek için çoğulcu bir yapı kurulmaya çalışıldığı söylenebilir.

$\mathrm{Bu}$ sisteme sahip göze çarpan ilk ülke Singapur'dur. Esasen siyasi tansiyon saikinden ziyade tamamen hoşgörü sebebiyle sıralı devlet başkanlığ modelinin benimsendiği görülmektedir. Singapur'da parlamenter sistem uygulanmakta ve devlet başkanı sembolik yetkiler ile donatılmıştır. Malay kökenlilerin 1970'den beri devlet başkanı seçilememesi gerçeğinden hareketle, toplumdaki tüm etnik yapıların devlet başkanlığı makamına ulaşabilir olması arzu edilerek Singapur Anayasası'nda 2016 yılında değişikliğe gidilmiştir. ${ }^{84}$ $\mathrm{Bu}$ değişiklik ile ülkede üç ana etnik grubun varlı̆̆ zikredilmiş̧ir: Malaylar, Çinliler ve "Hintli ve diğer azınlıklar" şeklinde bir sınıflandırmaya gidilmiştir. Devlet başkanının sıralı seçimi sisteminde geçmiş beş dönem ele alınmaktadır. Buna göre son beş dönemde hiç görev almamış bir etnik grup var ise bir sonraki devlet başkanı bu gruptan seçilecek ve başka etnik gruptan bir aday seçim yarışına alınmayacaktır. ${ }^{85}$ Mecliste çoğunluğa sahip Malay dışı etnik yapıların bahşettiği bu çoğulcu düzenleme ile 2017 devlet başkanlığı seçiminde Malay kökenli Halimah Jacob seçilmiştir. Tek aday olan Jacob, seçime gerek kalmadan devlet başkanı ilan edilmiştir. ${ }^{86}$ Liyakatin temel alınması şartıyla ${ }^{87}$, çok etnik yapılı ülkelerde siyasetin işlevsel bir şekilde devamı için bu tür paylaşımlar kamunun genel hoşnutluğu adına zaruri görülmelidir. ${ }^{88}$

${ }^{84}$ Mohamed Nawab Mohamed Osman/ Prashant Waikar, "The People's Action Party and the Singapore Presidency in 2017: Understanding the Contradictions Between State Discourse and State Practice", 2019, 59(2), Asian Survey, s. 382 385; Review of Specific Aspects of the Elected Presidency the Constitution of the Republic of Singapore (Amendment) Bill, 2016, $<$ nas.gov.sg/archivesonline/government_records/Flipviewer/grid_publish/1/1fd8053f8632-11e6-9af5-0050568939ad-28092016Cmd.7of2016/web/resources/_pdfs_/ GovernmentRecords_.pdf> Erişim Tarihi 18 Nisan 2021, s. 1-2.

85 Singapur Anayasas1, 1963, m. 19B.

86 Elections Department Singapore, Presidential Election Results, $<$ https://www.eld.gov.sg/ elections_past_results.html> Erişim Tarihi 18 Nisan 2021.

87 Osman, Waikar, 390.

88 Etnik çeşitliliğin Singapur'da ayrılıktan ziyade zenginlik olarak addedilmesi gerektiği ve 
Yazılı olmasa da uygulamadan kaynaklanan bir diğer sıralı devlet başkanlığı uygulamasını Nijerya'da görmek mümkündür. Singapur'un aksine sıralı devlet başkanlığı sistemi Nijerya'da dini rekabet ve çatışmayı önleme amacıyla benimsenmiştir. Zira Nijerya iki dinin oldukça güçlü olduğu ve bölgesel manada da ayrışmış bir ülkedir. Arap ve Osmanlı ardıl devletlerine komşu olan Nijerya'nın kuzey kesimleri, genel olarak Müslüman ve gelir düzeyi oldukça düşük olup; güney kesimler ise İngiliz sömürgeciliği ve yoğun misyonerlik faaliyetleri sonucu Hristiyanlaşmış ve petrol sebebiyle oldukça zenginleşmiştir. Ülkede iki büyük dinin etkin olması ve sömürgecilik döneminde hiçbir Müslüman liderin ülke yönetiminde etkin olamaması ve Müslüman bölgelerin ekonomik bakımdan geri bırakılması sonucu ülkede siyasi tansiyon, günümüze kadar harareti ile devam edegelmiştir. ${ }^{89}$ Buna karşın askeri darbe sonrası demokrasiye geçiş ile 1999 seçimlerinden sonra göreve gelen devlet başkanlarının seçiminde bir uzlaşı arayışı içerisinde olunmaya çalışılmıştır. Ülkenin en büyük partisi olan Halkın Demokratik Partisi (PDP), başkan adaylarını yapılan uzlaşı ile farklı dinlere mensup kişiler arasından çıkarmıştır. Seçilen devlet başkanlarının yardımcılarının da devlet başkanından farklı dine mensup olmasına dikkat edilmiştir. Nitekim son iki seçimde partiler arası güç dengesi değişmiş ve Müslüman adaylar seçimi kazanmış olsa da devlet başkan yardımcısı bağlamında farklı dine mensup kişi seçimi usulünde bir değişim yaşanmamıştır. Seçimin kazanan ve kaybedeninin her ikisinde de farklı dinlere ait ikili adaylıklar gösterilmiştir. ${ }^{90}$

halkın refahı ve mutluluğu için eşit imkanlar sunulmanın önemi hususunda daha fazla bilgi için Bkz. Chua Beng Huat, "Political Culturalism, Representation and the People's Action Party of Singapore", 2007, 14(5), Democratization, 913-918.

89 Max Siollun, What Britain Did to Nigeria, Hurst \& Company 2021; Chika J. B. Gabriel Okpalike/ Kanayo Louis Nwadialor, "The Evolution of Modern Nigeria through Missionary Activities Within Colonial Schemata, 1840-1960", International Conference of Interdisciplinary Studies, 2015; Aliyu Mukhtar Katsina, Colonialism, Post-colonialism and Ethnic Cleavages in Africa: Nigeria Since Independence, International Conference of the School of Arts and Social Sciences, 2012. Nijerya'da dinler arası çekişmenin daha detaylı boyutları ve farklı dine mensup insanların devlet kurumlarına, yönetim şekline dair görüşlerini yansıtan pek çok istatistiki veri için Bkz. Robert Ruby/ Timothy Samuel Shah, "Nigeria's Presidential Election: The Christian-Muslim Divide", 2007, <pewforum. org/2007/03/21/nigerias-presidential-election-the-christian-muslim-divide/> Erişim Tarihi 18 Nisan 2021.

90 Emmanuel O. Ojo, “The Religious Factor in Nigeria's 2019 Presidential Election”, 2020, 19(3), Journal of African Elections, s. 142-153; Nijerya'da etnik ve dini yapıların, devlet başkanlığı seçiminde seçmenlerin tercihi ve adayların belirlenmesi üzerinde ne gibi etkileri olduğu hususunda daha fazla bilgi için Bkz: Dele Babalola, "Ethno-Religious Voting in Nigeria: Interrogating Voting Patterns in the 2019 Presidential Election", 2020,109(4), The Commonwealth Journal of International Affairs, s. 377-385. 


\section{Birden Fazla Devlet Başkanı Seçilmesi: Bosna Modeli}

Devlet yönetiminde hangi kademede olursa olsun eş yetkiler ile donatılmış birden fazla kişiye bir makamın verilmediğini söylemek yanlış olmayacaktır. Ancak Bosna Hersek’te devletin her bir kurumunda eş yetkiler ile donatılmış kişilere "tek bir makamın" paylaştırıldığ1 görülmektedir. ${ }^{91}$ Meclis, Anayasa Mahkemesi gibi kolektif organlarda ise eş temsiliyet kuralı getirilerek yetki paylaşımının her noktaya yayılması sağlanmıştır. Ülkede özellikle yürütme konusunda hiçbir konuda ve makamda tek bir karar vericinin olmaması için özel uğraşlar verilerek bir anayasa hazırlanmıştır. Çalışmanın konusu açısından bakılacak olursa, ülkede üç adet devlet başkanı bulunmaktadır. Devlet başkanlarının her biri, ülkeyi oluşturan üç etnik yapıdan, yani Boşnak, Hırvat ve Sırplar tarafından ayrı ayrı seçilmektedir. ${ }^{92}$ Bosna Hersek'te benimsenen bu nevi şahsına münhasır yöntem ile ülkede etkin olan üç büyük etnik yapının eşit ama adil olmayan temsili sağlanmış olmaktadır. ${ }^{93}$

Bu uygulamayı değerlendirirken ilk bakışta oldukça çoğulcu ve kapsayııı bir uygulama olduğu hissiyatına kapılmak mümkündür. Hatta İsviçre'de ve Belçika'da olan bakanlık paylaşımlarında etnik ve dilsel paylaşımlar akla gelmektedir. ${ }^{94}$ Ancak bu paylaşımların bakanlar kurulu gibi "heyet" halinde teşekkül eden organlarda görülmesi normaldir. Devlet başkanlığı gibi bir kişinin sahip olması gereken bir makamda bu paylaşımı görmek şaşırtıcıdır.

91 Burada vurgulanan hususun, "bir makam" olduğunu söylemek gerekir. Elbette meclis, komisyon, anayasa mahkemesi veya herhangi bir kurulda birden fazla kişiye eşit imkanlarda makam tahsis edilmektedir. Ancak hangi kolektif yapı olursa olsun, bu yapıların içerisinde mutlaka bir kişi seçilmekte ve idare bu kişinin tekeline bırakılmaktadır. Ancak Bosna'da bahsedilen durum, tek bir kişinin karar alıcı noktada bulunması gereken kolektif olmayan makamların kolektifleştirilmesidir. Örneğin, Bosna Hersek Futbol Federasyonu'nun başında üç etnik yapıyı temsilen üç başkanın olması gerektiği kuralı sebebiyle Uluslararası Futbol Federasyonu'nun (FIFA) yaptırımlarına maruz kalınmış ve yıllar sonra atılan geri adım ile tek başkanlı yapıya geçilerek uğranılan yaptırımlar kaldırılmıştır. Bkz. Deutsche Welle, FIFA, UEFA Suspend Bosnia-Herzegovina over Tripartite Presidency, $<$ dw.com/en/fifauefa-suspend-bosnia-herzegovina-over-tripartite-presidency/a-14960205> Erişim Tarihi 18 Nisan 2021.

92 Bosna Hersek Anayasas1, 1995, m.5/1-a.

93 Zira ülke nüfusunun yarısını oluşturan etnik yapı ile 1/7'sini oluşturan bir etnik yapıya Devlet Başkanlığında, Mecliste, Anayasa Mahkemesi üyeliğinde vs. eşit yetkiler tanınmıştır. Bkz. Bosna Hersek Anayasas1, 1995; World Heritage Encyclopedia, Demographic History of Bosnia and Herzegovina, <http://www.self.gutenberg.org/Home> Erişim Tarihi 18 Nisan 2021.

94 Arend Lijphart, Patterns of Democracy, Government Forms and Performance in Thirty-Six Countries, 2. bs., Yale University Press, 2012, s. 33-34; 
Dikkat edilmelidir ki "her ülkede" etnik, dil, din gibi alanlarda farklı kesimler bulunmaktadır. Hatta bu yapıların oranları birbirine yakın da olabilmektedir. Ancak sadece Bosna'da, ülkeyi oluşturan etnik yapıların her birinin Devlet Başkanlık Konseyinde yeri olacağına dair hüküm bulunmaktadır. Esasen bu tür bir paylaşımı, birbiri ile hiçbir sorunu olmayan etnik veya dini gruplar arasında uzlaşı ile alınan bir karar sonrasında görmek gerekir. Zira getirilen paylaşım sistemi, oldukça önemli bir makamın paylaşımını öngörmekte ve siyasi tıkanıklıklara kolaylıkla sebep olacak türdendir. Ancak Bosna Hersek'teki durum bunun tam tersidir. Böyle bir hükmün getirilmesinin esas sebebini, bağımsızlığın sağlandığı 1995 yılına kadar ki süreçte Sırpların soykırım dahil pek çok savaş suçu işlemesi ve bu sebeple Bosna'daki üç büyük etnik grubun birbiri ile derin ayrılıklara düşmesi ve acı hadiselerin tekrar etmeme temennisi şeklinde görmek mümkündür. ${ }^{95}$ Sonuç olarak bu denli ayrışmanın yaşandığ1 bir toplumda getirilen bu uygulamanın "empoze edilmiş bir yönetim şekli" olduğunu zikretmek mümkündür. Nitekim pek çok akademik çalışmaya da konu olan bu üçlü yapı eleştirilerin odağı haline gelmiştir. ${ }^{97}$

\section{Ulusal Çoğunluk ve Bölgesel Başarı Şartı}

Devlet başkanının seçiminde getirilen ilave şartlara bakıldığında, incelenmeye değer bir diğer uygulama ise devlet başkanının sadece mutlak çoğunluğun oyu ile seçilmesinin yetmemesidir. Etnik veya dini gruplar arasında çatışmanın sık yaşandığı ve derin ayrılıkların olduğu kimi toplumlarda, devlet başkanının mutlak çoğunluğa ilaveten, ülkenin çeşitli coğrafi kesimlerinde de belli bir oranda başarıya ulaşmış olması aranmaktadır. Bu sistemin uygulandığ1 üç ülke bulunmaktadır. Nijerya, Kenya ve Endonezya'da farklı etnik ve dini grupların heterojen bir görünüm ile ülkenin belli coğrafyalarında yaşadığ 1 görülmektedir. Seçilecek devlet başkanının "sadece" ülkede çoğunlukta

95 Senada Zatagic, Bosna Hersek, in Abdurrahman Tekin, Ömer Temel, İlyas Furat Cengiz (Eds.) Osmanl1 Ardıl Devletlerinin Siyasal Sistemleri, 2. Bs, Adalet, 2020, s. 139.

96 Soeren Keil, Multinational Federalizm in Bosnia and Herzigovina, Taylor and Francis, 2016. Dayton Antlaşması ile kurulan bu düzen, savaşın Müslüman Boşnakların lehine döndüğü bir zamanda anlaşma masası kurulup, Müslüman Boşnaklara savaşın adeta masada kaybettirilmeye çalışılması olarak düşünülebilir.

97 Bkz. Zatagic, s. 137-172; Don Hays/ Jason Crosby, "From Dayton to Brussels", 2006, 175, United States Institute of Peace; Aydın Babuna, "European Integration, Bosnia-Herzegovina and Stability in the Western Balkans: A New Strategy", 2014, 19(2), Perceptions, s. 1-32; Ludovica Benedizione/Valentina Rita Scotti, Twenty Years After Dayton - The Constitutional Transition of Bosnia and Herzegovina, Rome, Luiss University Press, 2021; Aleksandar Savanovic, "Crises of Bosnia", 2013, 4(9), Mediterranean Journal of Social Sciences, s. 539-546. 
bulunan etnik veya dini bir yapıya mensup kişilerin tercihi ile seçilmemesi istendiği için bu uygulamanın hayata geçirildiği söylenebilir. Aksi taktirde çoğunlukçu bir yönetim tarzına sahip olunmuş ve azınlıkta olduğu için her daim yönetim dışı kalmış bir kesimin varlığı söz konusu olacaktır. Örneğin Nijerya'da bir Müslüman aday seçimi kazanacaksa, mutlaka Hristiyanların yaşadığı bölgelerden de belirli bir oranda oy alması gerekecektir. Aynı şekilde Kenya'da da seçimi kazanacak kişinin, farklı kabile ve etnik kökene mensup olan eyaletlerde belirli bir oranda oy alınması gerekmektedir.

Endonezya ve Kenya'da bir devlet başkanı adayının, seçimi ilk turda kazanabilmesi için geçerli oyların mutlak çoğunluğuna ulaşması gerekmektedir. Buna ilaveten adayın, Endonezya'da 34 şehrin en az yarısında \%20; Kenya'da ise 47 bölgenin en az yarısında \%25'ten fazla oy almış olması gerekmektedir. İlk turda adayın bu iki şartı da sağlayamaması durumunda ikinci tura, ilk turda en fazla oy alan iki aday katılmakta ve mutlak çoğunluğun oyunu alan aday devlet başkanı olmaktadır. ${ }^{98}$

Nijerya'da ise tek adayın seçime katılması durumunda, referandum şeklinde seçimler yapılır ve evet oylarının mutlak çoğunluğa ulaşması aranır. Buna ilaveten adayın, federal başkent de dahil, ülkedeki tüm eyaletlerin en az 2/3'ünde 1/3'ten fazla oy alması gerekmektedir. Bu şartların sağlanamamas1 durumunda seçimleryenilenmektedir. Görüldüğüüzere Nijerya' daseçilebilmek için "bölgesel başarı nisabı" diğer ülkelere göre yüksek tutulmuştur. İki kişinin seçime katılması durumunda da mutlak çoğunluğa ilaveten bölgesel başarı şartı aranmakta, hiçbir adayın başarılı olamaması durumunda ise seçimler yenilenmektedir. ${ }^{99}$ İkiden fazla adayın seçime girmesi durumunda ise seçimlerin ilk turu, yukarıda zikredilen usule göre yapılmaktadır. Hiçbir adayın bu şartı sağlayamaması durumunda ise en çok oyu alan birinci aday ikinci tura kalmaktadır. İkinci tura kalan "ikinci aday" ise aldığı oy sayısına göre değil, "kazandığı eyalet sayısına göre" belirlenmektedir. Seçimin ikinci turuna katılacak ikinci kişinin belirlenmesinde aynı sayıda eyalet kazanan iki adayın olması ihtimali de unutulmamış ve bu durumda ülke genelinde en çok oy alan adayın ikinci turdaki seçimlere katılması düzenlenmiştir. Böylece, ilk turda üçüncü olan adayın ikinci tura kalması gibi ilginç bir durum ile karşılaşılması da söz konusu olabilecektir. İkinci turda da mutlak çoğunluk ile bölgesel başarı şartı aranmaktadır. Ancak yine bir kazananın çıkmaması

\footnotetext{
98 Endonezya Anayasas1, 19, m. 6A/1,3,4; Kenya Anayasas1, 2010, m. 138/4,5.

99 Nijerya Anayasası, 1999, m. 133/1-a,b.
} 
durumunda üçüncü tur oylamalar yapılmakta ve burada sadece mutlak çoğunluk şartı aranmaktadır. ${ }^{100}$

Devlet başkanının seçiminde aranan bu şart ile ülkedeki farklı etnik ve dini kesimlerin desteğini almadan kimsenin bu makama oturmaması temin edilmeye çalışılmıştır. Her ne kadar Endonezya ve Kenya'da seçimin son turunda bölgesel başarı şartı aranmıyor olsa da bu durumu makul görmek gerekmektedir. Zira bu ülkeler başkanlık sistemi ile yönetilmekte ve devlet başkanı seçiminin katı kurallar sebebiyle sonuçlanamamasıyla iptal edilmesi ülkede bir yönetim krizine sebep olabilecektir. Buna karşın Nijerya'da ikiden fazla adayın katıldığı seçimin üçüncü turunda bölgesel başarı şartı aranmamaktadır. Diğer tüm ihtimallerde bu şart aranmaktadır. Bu durumu, ülkedeki dini rekabetin geldiği seviye ile açılamak mümkündür. Sonuç olarak, bugüne kadar üç ülkede de bölgesel başarı şartının sağlanamaması sebebiyle hiçbir zaman seçimler ikinci tura kalmamıştır. ${ }^{101}$

\section{Sonuç}

Modern demokrasilerde yürütmenin artan etkinliği göze çarpmaktadır. $\mathrm{Bu}$ artan etkinliği devlet başkanının sahip olduğu yetkilerdeki artıştan da tespit etmek mümkündür. Demokrasiye geçen ülkelerde de tercihin, güçlü devlet başkanından yana olduğu görülmektedir. Artan bu yetkiler, devlet başkanlarının halk tarafından seçilmeye başlanması ile sonuçlanmaktadır. Örneğin demokrasiye geçen Orta ve Doğu Avrupa ülkeleri Romanya, Slovenya, Hurvatistan, Surbistan, Ukrayna ve Kuzey Afrika ülkeleri Cezayir, Tunus ve 2012-2014 arasında Mısır'da olduğu gibi devlet başkanının halk tarafından seçilmesi yönünde bir tercihin yapıldığı göze çarpmaktadır. Hatta parlamenter sistem olarak kabul edilen Avusturya, Portekiz, Singapur ve İzlanda gibi ülkelerde de devlet başkanının halk tarafından seçilme usulünün benimsendiği görülmektedir.

Günümüzde Dünya'daki ülkelerin çoğunda devlet başkanı halk tarafından seçilir hale gelmiştir. Sayının fazlalığı, uygulamada farklı seçim sistemlerinin benimsenmesine ve hatta bu sistemlerin ülke gerçeklerinden hareketle yoğurularak farklılaştırılmasına da yol açmıştır. Uygulanan seçim sistemlerini iki ana başlık altında, tek turda biten ve bitmeyebilen seçim sistemleri şeklinde ayırmak mümkündür. Bu iki ana tasnif altında incelenen

\footnotetext{
100 Nijerya Anayasas1, 1999, m. 134/1,2,3,4,5.

101 Adam Carr, Election Arcive, <psephos.adam-carr.net> Erişim Tarihi 18 Nisan 2021.
} 
7 farklı seçim sisteminin kendine has olumlu ve olumsuz yanları mevcuttur. Hangi seçim sisteminin en iyi olduğunu söylemek elbette ki mümkün değildir. Zira her sistemin ülkeden ülkeye farklı sonuçlar vermesi doğal bir durumdur.

Uygulanan seçim sistemleri incelenirken, seçim sistemlerinde tespit edilen birtakım ilave şartların varlığı da göze çarpmaktadır. İlave şartların getirilmesi ile seçilecek kişiye ve devlet başkanlığı makamına toplum nezdinde duyulan bağlılığın artırılması amaçlanmıştır. Bu şartların ilki, devlet başkanının daha fazla kişinin seçime katıldığı bir yarışmada belirlenmesini sağlayan seçime katılım kotasıdır. İkincisi, sıralı devlet başkanlığı şartı olup, farklı etnik ve dini grupların sırayla devlet başkanlığı makamına oturması amaçlanmaktadır. Üçüncü tespit edilen şart, etnik açıdan her kesimin kendi devlet başkanını seçmesi ve makamın bu kişilerce bir konsey şeklinde yürütülmesidir. Son şart ise devlet başkanı olarak seçilebilmek için sadece ülke çapında çoğunluğun elde edilmesi değil, buna ilaveten etnik ve dini grupların yaşadığ bölgelerden de asgari bir oranda oy alınması gerektiğidir. Elbette bu noktada da her bir şart için olumlu ve olumsuz sonuçlar çıkarmanın mümkün olduğu zikredilmelidir.

Son olarak belirtilmedir ki bu çalışmada, Türkiye'de devlet başkanının nasıl seçilmesi gerektiği üzerine bir değerlendirme veya öneri yapılmamaktadır. Zira bu ayrı bir çalışmanın konusudur. Burada Dünya'da uygulanan farklı sistemler incelenmiş ve söz konusu çalışmayı yapacak akademisyen ve siyasilere rehber olunması amaçlanmıştır.

\section{Kaynakça}

Abebe A/ Bulmer E, Electing Presidents in Presidential and Semi-Presidential Democracies, IDEA, 2019.

Anayasalar, $\quad<$ https://www.constituteproject.org/constitutions?lang=en> Erişim Tarihi 10 Ocak 2021.

Anayurt Ö, Anayasa Hukuku Genel Kısım, 3. Bask1, Seçkin, 2020.

Babalola D, "Ethno-Religious Voting in Nigeria: Interrogating Voting Patterns in the 2019 Presidential Election", 2020, 109(4), The Commonwealth Journal of International Affairs, 109(4), 2020.

Babuna A, "European Integration, Bosnia-Herzegovina and Stability in the 
Western Balkans: A New Strategy", 2014, 19(2), Perceptions, s. 1-32.

Benedizione L/ Rita Scotti, V, Twenty Years After Dayton - The Constitutional Transition of Bosnia and Herzegovina, Luiss University Press, 2021.

Best J, The Case against Direct Election of the President: A Defense of the Electoral College, Ithaca, Cornell University Press, 1971.

Boudreaux P, “The Electoral College and its Meager Federalism”, 2004, 88(2), Marquette Law Review, s. 195-249.

Bouton L/ Gratton G, "Majority Runoff Elections: Strategic Voting and Duverger's Hypothesis", 2015, 10(2), Theoretical Economics, s. 283314.

Bulut, N, Siyasal İktidar Tipleri ve Bir Siyasal İktidar Tipi Olarak (Modern) Devlet, 2020, <http://cdn.istanbul.edu.tr/FileHandler2.ashx?f=siyasaliktidar-tipleri-vebir-siyasal-tipi-olarak-modern-devlet.pdf $>\quad$ Erişim Tarihi 18 Nisan 2020.

Calabresi S. G/ Berghausen, M. E/ Albertson, S, "The Rise and Fall of the Separation of Powers", 2012, 106(2), Northwestern University Law Review, s. 527-550.

Carr A, Election Arcive, <psephos.adam-carr.net> Erişim Tarihi 18 Nisan 2021.

Council of Europe, Observation of the Presidential Election in North Macedonia, 2019, <assembly.coe.int/nw/xml/XRef/Xref-XML2HTMLen.asp?fileid=27699\&lang=en $>$ Erişim Tarihi 18 Nisan 2021.

Croissant A, "Electoral Politics in South Korea", in Aurel Croissant, (Ed.) Electoral Politics in Southeast and East Asia, Friedrich-Ebert-Stiftung, 2002.

Deutsche Welle, FIFA, UEFA Suspend Bosnia-Herzegovina over Tripartite Presidency, <dw.com/en/fifa-uefa-suspend-bosnia-herzegovina-overtripartite-presidency/a-14960205> Erişim Tarihi 18 Nisan 2021.

Elections Department Singapore, Presidential Election Results, $<$ https://www. eld.gov.sg/elections_past_results.html> Erişim Tarihi 18 Nisan 2021.

Election Guide, Republic of Bulgaria Election for President, <electionguide. org/elections/id/2992/> Erişim Tarihi 18 Nisan 2021.

Election Guide, Republic of North Macedonia Election for President, <electionguide.org/elections/id/2790/> Erişim Tarihi 18 Nisan 2021. 
Elections Ireland, Presidential Election 27 October 2011, <electionsireland. org/counts.cfm?election $=2011 p \&$ cons $=194>$ Erişim Tarihi 18 Nisan 2021.

Eren A, Anayasa Hukuku Dersleri, 2. Bask1, Seçkin, 2020.

European Union Election Observation Mission, Presidential and Parliamentary Elections Nicaragua 2006, <aceproject.org/ero-en/regions/americas/ $\mathrm{NI} /$ nicaragua-eo-reports/nicaragua-presidential-and-parliamentaryelections> Erişim Tarihi 18 Nisan 2021.

Favereu L, Droit Constitutionnel, Paris, Dallos, 1998.

Federal Election Commission, Election results, $<$ fec.gov/introductioncampaign-finance/election-and-voting-information/> Erişim Tarihi 18 Nisan 2021.

Gabriel Okpalike C. J. B/ Nwadialor, K. L, "The Evolution of Modern Nigeria through Missionary Activities Within Colonial Schemata, 1840-1960", International Conference of Interdisciplinary Studies, 2015.

Gamarra E, "Hybrid Presidentialism and Democratization: The Case of Bolivia." in Scott Mainwaring, Matthew Soberg Shugart, (Eds.) Presidentialism and Democracy in Latin America, Cambridge University Press, 1997.

General Election Committee of Mongolia, Results of the Second Vote of the Presidential Election of Mongolia 2017, <gec.gov.mn/blog/2188> Erişim Tarihi 18 Nisan 2021.

Gözler K, Devlet Başkanları, 2. Bask1, Ekin, 2016.

Hakyemez Y. Ş, “Anayasa Mahkemelerinin Geleneksel İşlevi Bağlamında Günümüzde Ortaya Çıkan İki Sorun: Yerindelik Denetimi Tartışmaları ve Ulusalüstü Örgüte Üye Devletlerdeki Anayasa Yargısının Konu Bakımından Sinırlandırılması", 2007, 24, Anayasa Yargıs1, s. 525-568.

Hardaway R. M, The Electoral College and the Constitution: The Case for Preserving Federalism, Praeger, 1994.

Hays D/ Crosby J, "From Dayton to Brussels", 2006, 175, United States Institute of Peace.

Horowitz D. L, A Democratic South Africa: Constitutional Engineering in a Divided Society, University of California Press, 1991.

Huat C. B, "Political Culturalism, Representation and the People's Action 
Party of Singapore", 2007, 14(5), Democratization, s. 911-927.

Instituto Nacional Electoral Mexicali, Estadísticas y Resultados Electorales, <portalanterior.ine.mx/archivos3/portal/historico/contenido/ Elecciones/> Erişim Tarihi 18 Nisan 2021.

Jones M. P, "Presidential and Legislative Elections", in Erik S. Herron, Robert

J. Pekkanen, Matthew S. Shugart, (Eds.) The Oxford Handbook of Electoral Systems, Oxford University Press, 2018.

Jorge L. R, "Bolivia", in Dieter Nohlen, (Ed.) Elections in the Americas a Data Handbook, Vol. II, Oxford University Press, 2005.

Katsina A. M, Colonialism, Post-colonialism and Ethnic Cleavages in Africa: Nigeria Since Independence, International Conference of the School of Arts and Social Sciences, 2012.

Kaufman I. R, "The Essence of Judicial Independence”, 1980, 80(4), Colombia Law Review, s. 671-701.

Keil S, Multinational Federalizm in Bosnia and Herzigovina, Taylor and Francis, 2016.

Keyssar A, Why Do We Still Have The Electoral College?, Harvard University Press, 2020.

Kochmar-Tymoshenko, S, Ukraine's heated presidential campaign most expensive ever, 2019, <euromaidanpress.com/2019/03/28/ukrainesheated-presidential-campaign-most-expensive-ever/> Erişim Tarihi 18 Nisan 2021.

Lewis W. A, Politics in West Africa, Oxford University Press, 1965.

Lijphart A, "The Alternative Vote: A Realistic Alternative for South Africa?", Politikon, 1991, 18(2), s. 91-101.

Lijphart A, Patterns of Democracy, 2. Bask1, Yale University Press, 2012.

Lijphart A, Patterns of Democracy, Government Forms and Performance in Thirty-Six Countries, 2. bs., Yale University Press, 2012.

Linz J. J, "Presidential or Parliamentary Democracy: Does It Make a Difference?" in Juan J. Linz, Arturo Valenzuela, (Eds.) The Failure of Presidential Democracy, Johns Hopkins University Press, 1994.

Linz J. J, "Perils of Presidentialism”, Journal of Democracy, s. 51-69.

Mayorga R. A, "Electoral Reform in Bolivia: Origins of the Mixed-Member Proportional System", in Matthew Soberg Shugart, Martin P., Wattenberg, 
(Eds.) Mixed-Member Electoral Systems The Best of Both Worlds?, Oxford University Press, 2001.

Mohamed-Osman M. N/ Waikar P, “The People's Action Party and the Singapore Presidency in 2017: Understanding the Contradictions Between State Discourse and State Practice", Asian Survey, s.382-405.

National Archives, 2020 Electoral College Results, <archives.gov/electoralcollege/2020> Erişim Tarihi 18 Nisan 2021.

Ojo E. O, “The Religious Factor in Nigeria's 2019 Presidential Election”, Journal of African Elections, s. 136-155.

OSCE, Republic of Serbia Parliamentary and Early Presidential Elections 6 and 20 May 2012, <osce.org/files/f/documents/d/e/92509.pdf> Erişim Tarihi 18 Nisan 2021.

Özsoy-Boyunsuz Ş, Başkanlı Parlamenter Sistem, On İki Levha, 2014.

Review of Specific Aspects of the Elected Presidency the Constitution of the Republic of Singapore (Amendment) Bill, 2016, <nas. gov.sg/archivesonline/government_records/Flipviewer/ grid_publish/1/1fd8053f-8632-11e6-9af5-0050568939ad28092016Cmd.7of2016/web/resources/_pdfs_/GovernmentRecords pdf> Erişim Tarihi 18 Nisan 2021.

Roskin M. G/ Cord Robert L/ Medeiros J A/ Jones W. S, Political Science an Introduction, 12. bs., Pearson, 2012.

Ruby R/ Shah T. S, "Nigeria's Presidential Election: The Christian-Muslim Divide", 2007, <pewforum.org/2007/03/21/nigerias-presidentialelection-the-christian-muslim-divide/> Erişim Tarihi 18 Nisan 2021.

Sartori G, "Political Development and Political Engineering", in J.D. Montgomery, A.O. Hirschman, (Eds.) Public Policy, Harvard University Press, 1968.

Savanovic A, "Crises of Bosnia", 2013, 4(9), Mediterranean Journal of Social Sciences, s. 539-546.

Shugart M. S/ Taagepera R, "Plurality versus Majority Election of Presidents: A Proposal for a "Double Complement Rule", Comparative Political Studies, s. 323-348.

Shugart M. S, "Extreme Electoral Systems and the Appeal of the MixedMember Alternative", in Matthew Soberg Shugart, Martin P., Wattenberg, 
(Eds.) Mixed-Member Electoral Systems The Best of Both Worlds?, Oxford University Press, 2001.

Sierra Leone National Election Commission, Presidential Election Results, $<$ nec.gov.sl/site/elections_results $>$ Erişim Tarihi 18 Nisan 2021.

Singapoure Elections Department, Presidential Election Results, <eld.gov. sg/elections_past_results_presidential.html\#Y2011> Erişim Tarihi 18 Nisan 2021.

Siollun M, What Britain Did to Nigeria, Hurst \& Company 2021.

Solijonov A, Voter Turnout Trends around the World, IDEA, 2016.

Tanör B/ Yüzbaşığlu N, 1982 Anayasasına göre Türk Anayasa Hukuku, 20. Bask1, Beta, 2020.

Teehankee J, "Electoral Politics in the Philippines", in Aurel Croissant, (Ed.) Electoral Politics in Southeast and East Asia, Friedrich-Ebert-Stiftung, 2002.

Tekin A, Liberal Anayasal Sistemlerde Parlamento İçi Muhalefetin Rolü, On İki Levha, 2019.

Tekin A/ Temel, Ö, "Political and Constitutional Developments in Tunisia and Egypt in the aftermath of the Arab Spring", Law \& Justice Review, s. 193-239.

Temel Ö, "Kuzey Makedonya", in Abdurrahman Tekin, Ömer Temel, İlyas

Firat Cengiz, (Eds.) Osmanlı Ardıl Devletlerinin Siyasal Sistemleri, 2. Bs, Adalet, 2020.

United States Code, Title 3, 1948, <govinfo.gov/content/pkg/USCODE2019-title3/pdf/USCODE-2019-title3.pdf> Erişim Tarihi 18 Nisan 2021.

World Heritage Encyclopedia, Demographic History of Bosnia and Herzegovina, http://www.self.gutenberg.org/Home Erişim Tarihi 18 Nisan 2021.

Zatagic S, "Bosna Hersek", in Abdurrahman Tekin, Ömer Temel, İlyas Firat Cengiz, (Eds.) Osmanlı Ardıl Devletlerinin Siyasal Sistemleri, 2. Bs, Adalet, 2020. 
